\title{
3. CRETACEOUS CALCISPHAERULIDS FROM DSDP LEG 41, EASTERN NORTH ATLANTIC
}

Uwe Pflaumann, Geologisch-Paläontologisches Institut der Universität Kiel, Olshausenstr. 40/60, 23 Kiel, Federal Republic of Germany and

Valery A. Krasheninnikov, Geological Institute of the USSR Academy of Sciences, Moscow, USSR

\begin{abstract}
Nine new species, one new forma, two other forms in open nomenclature, and two previously known species of Pithonella, attributed to the incertae sedis family Calcisphaerulidae are described from Lower and Upper Cretaceous sediments from the North Atlantic Ocean off northwest Africa collected during Leg 41 at Sites 369 and 370 (Figure 1) Features of isolated specimens such as shape, wall structure, number of layers forming the wall, crystal shape, and arrangement, as well as presence or absence of pores are used to establish new species and groups.

The stratigraphically and regionally restricted occurrences and ranges of the species here described have to be confirmed by additional investigations on further material from other regions to state the stratigraphic and paleoecologic value of these microfossils.
\end{abstract}

\section{INTRODUCTION}

Bolli (1974) described new species of the incertae sedis family Calcisphaerulidae from Jurassic and Cretaceous sediments of the Eastern Indian Ocean. Leg 41 sediments also yielded calcisphaerulids which could be isolated. Because of their stratigraphic value the calcisphaerulids from Leg 41 have been treated by the same methods as described by Bolli (1974).

It became clear during shipboard investigations that there are various species in the Cretaceous material recovered. Calcisphaerulids can be distinguished by light microscope using their shape and surface texture as criteria. They are sometimes fairly common in the $>63 \mu \mathrm{m}$ fraction.

The shore-based investigations had been done by scanning microscope (Stereoscan Mark 2, Cambridge, Inc.) at the Kiel University.

The main goal of this paper is to show the stratigraphic range and geographic distribution of calcisphaerulids and to encourage additional investigations of these fossils both in land and oceanic sediments.

\section{OCCURRENCES}

Calcisphaerulids were found in sediments from Hole $369 \mathrm{~A}\left(26^{\circ} 35.55^{\prime} \mathrm{N}, 14^{\circ} 59.56^{\prime} \mathrm{W}\right)$, in Cores 36 to 38 , dated by foraminifera as Campanian to Maestrichtian: at Site $370\left(32^{\circ} 50.25^{\prime} \mathrm{N}, 10^{\circ} 46.56^{\prime} \mathrm{W}\right)$, in Cores 20 to 24 , dated as Albian to Cenomanian; 28, CC (late Aptian to early Albian), in Core 32 (Barremian), in Cores 35 to 39 (Hauterivian), and in Cores 40 through 48 (late Valanginian to early Hauterivian).

The sediments from Site 370 which contain calcisphaerulids are dark greenish nanno-bearing claystone and shale, and greenish silty clay, claystone, and marlstone. The calcisphaerulids from Site 369

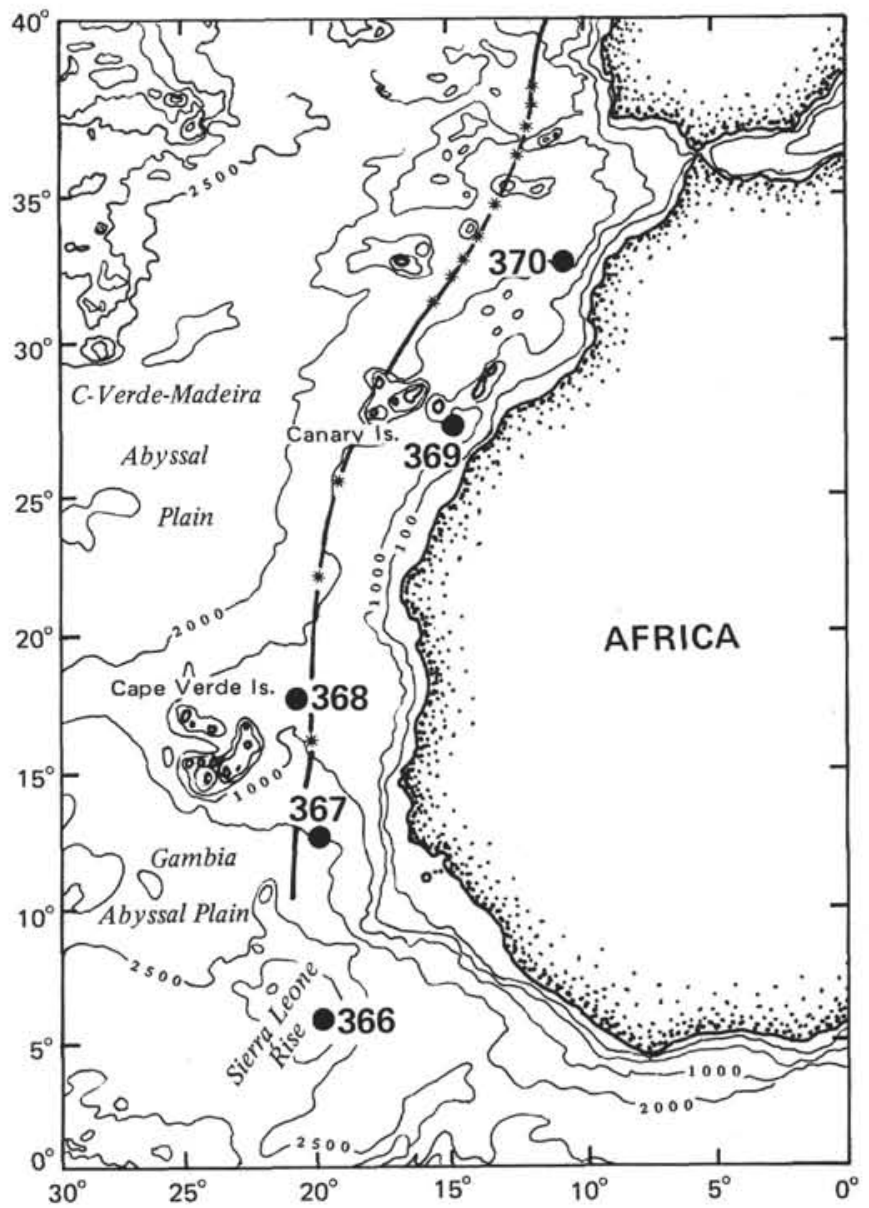

Figure 1. Location of Leg 41 sites.

range from bluish-white to greenish-gray nannobearing marl and nanno marlstone. 
TABLE 1

Occurrence of Pithonella Species in Leg 41 Materials

\begin{tabular}{|c|c|c|c|c|}
\hline $\begin{array}{c}\text { Sample } \\
\text { (Interval } \\
\text { in } \mathrm{cm} \text { ) }\end{array}$ & 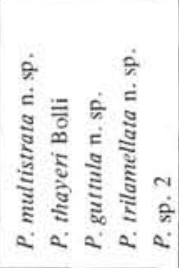 & 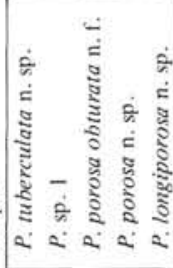 & 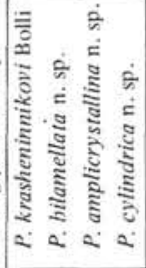 & Age \\
\hline $\begin{array}{l}\text { Hole } 369 \mathrm{~A} \\
36-3,23-25\end{array}$ & & & ++ & Maestrichtian \\
\hline $\begin{array}{l}37-4,63-65 \\
37-5,63-65 \\
37-6,43-45 \\
38-2,63-65 \\
38-5,53-55\end{array}$ & & + & $\begin{array}{lllll}+ & + & & + \\
+ & & & + \\
& & + & \\
+ & & & \\
+ & & & \end{array}$ & $\begin{array}{l}\text { Maestrichtian } \\
\text { to } \\
\text { Campanian }\end{array}$ \\
\hline $\begin{array}{l}\text { Site } 370 \\
20-1,73-75 \\
21-1,23-25 \\
21-2,63-65 \\
22-1,73-75 \\
23-1,93-95 \\
24-5,73-75 \\
28, \overline{C C}\end{array}$ & $---\frac{1}{?}$ & 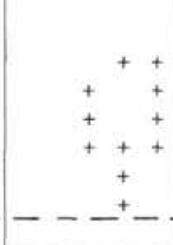 & --- & $\begin{array}{l}\text { Cenomanian } \\
\text { to } \\
\text { latest Albian } \\
\text { Aptian to Albian }\end{array}$ \\
\hline$\frac{33, \mathrm{CC}}{34-273.75}$ & ++ & + & & $\begin{array}{l}\text { Aptian to } \\
\text { Barremian } \\
\end{array}$ \\
\hline$\frac{34-2,73-75}{35-5,27-29}$ & + & & ---- & $\begin{array}{c}\text { Barremian } \\
\text { Late Hauterivian }\end{array}$ \\
\hline $\begin{array}{l}\overline{38-2,9}, \overline{8-1} 0 \overline{0} \\
39-\overline{1}, 5 \overline{8-60} \\
40-1,39-41 \\
42-2,72-74 \\
43-3,107-109 \\
44-1,71-73 \\
45-2,72-74 \\
45, C C \\
46-5,34-36 \\
48-1,65-67\end{array}$ & $\begin{array}{rr}- & + \\
+ & + \\
+ & + \\
++ & + \\
+ & + \\
& ++ \\
& + \\
+ & \\
+ & + \\
+? & \end{array}$ & $-\cdots$ & ---- & $\begin{array}{l}\text { Hauterivian } \\
\text { to } \\
\text { Valanginian }\end{array}$ \\
\hline
\end{tabular}

\section{REGIONAL DISTRIBUTION}

Banner (1972) discusses the regional distribution of Pithonella ovalis. According to him, it is probable that the populations occur in abundance in areas of nutrient-rich surface waters and areas of high primary productivity (upwelling areas). His map locates upwelling for the Late Cretaceous in a region off northwest Africa where the gyres of the Tethys and the North Atlantic met with opposite current directions. The branching gyre of the Tethys produced a divergence upwelling. Wiedmann (1975) believes that cold upwelling waters caused the "boreal" faunal character in land sections of the early Cenomanian of southern Morocco.

Relatively high organic carbon contents and the presence of plant fragments and fish debris support this hypothesis. However, Radiolaria and other siliceous microfossils which had been used as upwelling indicators are missing. The black shale of Site 367 contains about three times the normal organic matter in deep-sea sediments, but calcisphaerulids were not found there. This may be the result of either dissolution or there simply never having been any deposited there.

The calcisphaerulids of Site 369 , however, were isolated from normal pelagic sediments. The knowledge of regional distribution of the calcisphaerulids is too poor for the statement that they are upwelling indicators.

\section{MORPHOLOGY}

Most of the known species of the calcisphaerulids have been studied in thin sections (Bolli, 1974) or scanning electron microscopy (Banner, 1972; Bolli, 1974; and Villain, 1975). We follow the criteria of Bolli (1974) for taxonomic determinations. Therefore we use a single generic name, though calcisphaerulids with pores or slit-like pores may belong to an independent genus. We used features such as general shape, position and type of aperture, number of layers forming the wall, structure of a layer, outline of crystals and their arrangements, and character of the surfaces for establishing species.

We compared our specimens with those of Bolli (1974), and if we met new combinations of features, then we erected new species.

We used only the most distinct morphologic characteristics. In reality, we realize that the variability is much greater.

We group the species with similar morphology together. The stratigraphical comparison with Bolli's (1974) species show that there is only one species in common. The majority is treated as new species. Bolli (1974) described his species from levels ranging in age from Late Jurassic, from Aptian and Albian, and from a heterogeneous sample of probably Coniacian to Santonian. Our specimens cover not only these levels, but also some additional Cretaceous intervals.

\section{TAXONOMY}

Family incertae sedis CALCISPHAERULIDAE Bonet, 1956

We follow Bolli (1974) in the use of this family name. It embraces the genera Pithonella. Cadosina. Cadosinella. Stomiosphaera, and Andriella.

\section{Genus PITHONELLA Lorenz, 1901}

Diagnosis: Test single-chambered, spherical to ovoidal, wall consisting of calcite crystals of varying sizes, shapes, and arrangements, forming one or more layers. Apertures or pores sometimes present.

Known stratigraphic range: Jurassic to Upper Cretaceous. Bolli (1974) describes Pithonella species from turbidites not older than Late Cretaceous age.

Comments: We also believe that Pithonella may be a cyst stage belonging to algae or some unknown microorganism (compare Bein and Russ, 1976).

We subdivide the genus into the following morphological groups: Group I. Single-layered wall, spherical outline, without visible additional pores: $P$. thayeri and $P$. sp. 1 .

Bolli's (1974) species $P$. carteri, $P$. monighti, P. patriciagreeleyae. $P$. rockeri, $P$. gustavsoni, $P$. johnstonei belong to this group, as well as the subspherical $P$. quiltyi.

Group II. Single-layered wall, spherical outline, with pores: $P$. porosa n. sp., P. porosa forma obturata n. forma, P. longiporosa $\mathrm{n}$. sp.

Group III. Single-layered wall, oval outline: P. amplicrystallina $\mathrm{n}$. sp.

We also add Bolli's (1974) species $P$. veeversi to this group.

Group IV. Multilayered wall, spherical outline: $P$. trilamellata $\mathrm{n}$. sp., $P$. multistrata n. sp.

$P$. helentappanae, $P$. loeblichi, $P$. heirtzleri, as well as the subspherical P. edgari, P. sheilasantawae. P. cooki of Bolli (1974), are added to this group.

Group V. Multilayered wall, oval outline: $P$. guttula, n. sp., $P$. krasheninnikovi Bolli, P. bilamellata $\mathrm{n}$. sp., P. cylindrica $\mathrm{n}$. $\mathrm{sp}$. 
TABLE 2

Ranges of SEM Investigated Pithonella Species in Jurassic and Cretaceous Sediments (according to Banner, 1972, Bolli, 1974, and this paper)

\begin{tabular}{|c|c|c|}
\hline & & 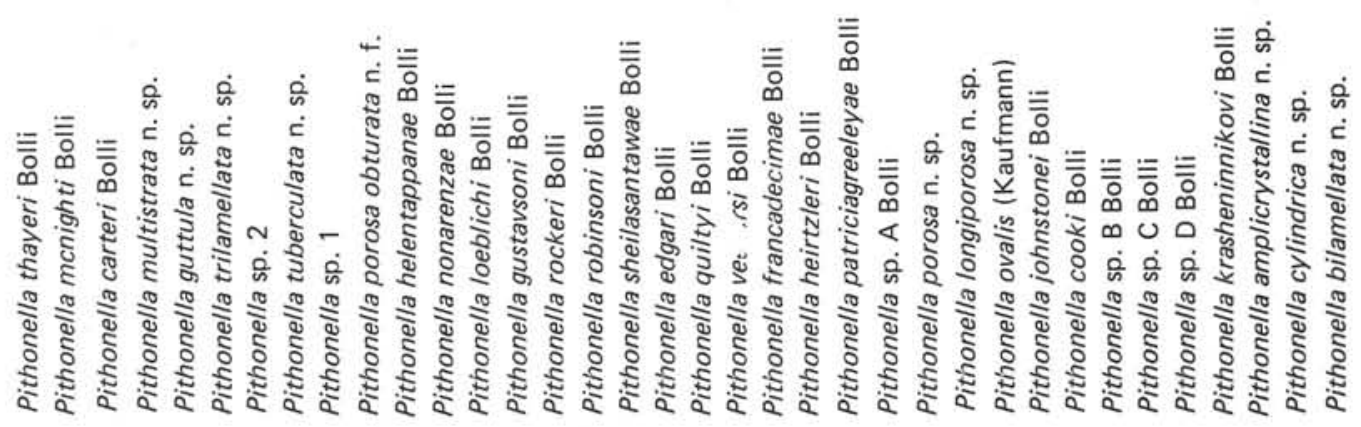 \\
\hline \multirow{6}{*}{ 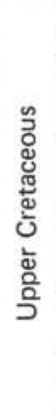 } & Maestrichtian & \\
\hline & Campanian & \\
\hline & Santonain & \\
\hline & Coniacian & \\
\hline & Turonian & \\
\hline & Cenomanian & \\
\hline \multirow{6}{*}{ 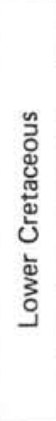 } & Albian & \\
\hline & Aptian & - \\
\hline & Barremian & \\
\hline & Hauterivian & \\
\hline & Valanginian & \\
\hline & Berriasian & \\
\hline \multirow{3}{*}{ 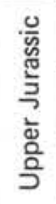 } & Tithonian & \\
\hline & Kimmeridgian & \\
\hline & Oxfordian & \\
\hline
\end{tabular}

The criteria used to establish these groups include test shape, presence or absence of main or slit-like apertures, and quantity of different layers.

\section{Pithonella thayeri Bolli \\ (Plate 1, Figures 1-5)}

Pithonella thayeri Bolli, 1974, p. 853, pl. 1, fig. 9-12, pl. 8, fig. 9-12, pl. 9, fig. 1-12, pl. 21 , fig. 3 .

Description of species: Test globular to subspherical, composed of a single-layered wall of about $6 \mu \mathrm{m}$ in thickness which is formed by crystals 5 to $12 \mu \mathrm{m}$ in diameter. The outer surface is very rough although single crystals seen on the outer surface are mostly rounded. Apertures were not seen with one exception of a questionable specimen (Plate 1, Figure 3), whose outer surface is not as coarse as is typical. Its aperture measures $25 \mu \mathrm{m}$ in diameter and is surrounded by radially oriented plate-like crystals $3 \times 2 \times 2 \mu \mathrm{m}$ in size. However, the crystal size and shape away from the aperture takes on more the outline of a normal $P$. thayeri. We have not observed an inner surface because all broken specimens were filled with sediment.
Sometimes the interspaces between coarse crystals are not filled with finer ones so that the surface pseudopores remain open. Diagenesis may be a major factor controlling the outline of the outer test surface so it is possible that our Pithonella thayeri is only a variant of another species.

There are affinities to Pithonella trilamellata $\mathrm{n} . \mathrm{sp}$., but the multilayered character is missing. Intergrades are assigned to Pithonella tuberculata $\mathrm{n} . \mathrm{sp}$., which is recorded in only one sample and it has a double-layered texture. The outer surface is similar to the doublelayered $P$. loeblichi. (Dimensions: diameter $45-80 \mu \mathrm{m}$.)

Occurrence: Section 370-48-1 to Sample 370-33, CC.

Age: Valanginian to Barremian.

Bolli (1974) recorded this species from Upper Oxfordian to Tithonian sediments off NW-Australia.

Pithonella sp. 1

(Plate 1, Figures 6a, b)

Description of species: Test globular, the outer surface formed by obliquely arranged, nearly smooth large crystals of different sizes. 
This arrangement suggests there may have been a diagenetic influence. There seems to be remnants of very small crystals between the large ones like that of the inner layer of Pithonella guttula $\mathrm{n}$. sp.

Only one sample (370-34-2) yielded specimens of this type, so it is questionable whether or not this is a separate species.

Dimensions: Diameter around $50 \mu \mathrm{m}$.

Occurrence: Section 370-34-2, rare.

Age: Barremian.

Pithonella porosa n. sp.

(Plate 2, Figures 3, 5; Plate 3, Figures 1, 2)

Derivatio nominis: porosa (Latin): with pores.

Holotype: Plate 2, Figures 4a, b.

Paratypes: Plate 2, Figures 5a, b, c; 6a, b, c; 7.

Type locality: DSDP Leg 41, Sample $370-24-5,73-75 \mathrm{~cm}$

Type level: Latest Albian to Cenomanian.

Diagnosis: Test globular, consisting of a single calcite layer, penetrated by irregularly distributed rounded to elongate pores.

Description: Test globular, consisting of one layer of about $6 \mu \mathrm{m}$ in thickness. The crystal growth, as seen from the outside, varies gradually from the interior (where the diameters visible are around $0.2 \mu \mathrm{m}$ ) to the outer surface (where the diameters measure between 2 and $5 \mu \mathrm{m}$ ). The crystals at the outer surface have a fairly irregular. closely packed arrangement. Pores of about $4 \mu \mathrm{m}$ diameter are irregularly distributed but with nearly equal distances between them (12 to $15 \mu \mathrm{m}$ ). The shapes of the pores vary between circular and elongate, the longest slits observed measure $8 \mu \mathrm{m}$ in length. The pores are sometimes surrounded by rosette-like crystals, which may be of diagenetic origin.

A main aperture of about $20 \mu \mathrm{m}$ diameter is present, in rare cases, showing no special patterns of crystal structure or arrangement in its surroundings.

Specimens from the deeper parts of Site 370 have pores that are closed and not visible at the outer surface. In these specimens, the outer surface consists of calcite crystals with diameters between I and $7 \mu \mathrm{m}$ without a visible special pattern. We describe these forms as Pithonella porosa forma obturata, new form.

Dimensions of holotype: Diameter $74 \mu \mathrm{m}$.

Dimensions of paratypes: Diameter $65-75 \mu \mathrm{m}$.

Occurrence: DSDP Leg 41 Site 370, Sections 24-5 to 20-1.

Age: Latest Albian (Rotalipora apenninica Zone) to Cenomanian/Turonian.

Pithonella porosa $\mathrm{n}$. $\mathrm{sp}$. differs from Pithonella longiporosa by having an outer surface that is more coarsely crystalline and rounded pores being more common than in Pithonella longiporosa. In addition, the slit-like pores are less strongly marked.

\section{Pithonella porosa n. sp. forma obturata n. forma}

(Plate 3, Figures 1-3)

Derivatio nominis: obturata (Latin): obturated.

Type specimen: Plate 3, Figures $1 \mathrm{a}, \mathrm{b}$.

Type locality: DSDP Leg 41, Site 370, Sample 21-2 $(63-65 \mathrm{~cm})$.

Type level: Latest Albian to Cenomanian.

Diagnosis: A new form of Pithonella porosa n. sp., with closed pores.

Description: Test globular, distinct aperture not recorded, wall consisting of one layer, formed by crystals which are randomly distributed in a radial array. As observed from the outer surface, their sizes vary between 1 and $7 \mu \mathrm{m}$ in diameter, without visible special patterns.

Occasionally specimens with a more or less circular "opening" were found. The diameter of the openings range up to $40 \%$ of the diameter of the test. These openings are considered artifacts because the borders have irregular outlines and no special wall structures around the opening were detected. The inner surface of the test is formed like that of Pithonella porosa n. sp.: small crystals about 0.5 $\mu \mathrm{m}$ diameter form a relatively rough but even inner surface. Pores of $5 \mu \mathrm{m}$ diameter are visible but closed by rough crystals which sometimes grow into the interior with crystals elevating the normal inner surface. The pores are numerous and the distances between them are about 4 to $5 \mu \mathrm{m}$.

There are some specimens in Sample 370-21-2, 63-65 cm, which show pore-like openings of about $3 \mu \mathrm{m}$ diameter on the outer surface. These specimens show an intergradation to Pithonella porosa $\mathrm{n} . \mathrm{sp}$., the differences being only additional, possibly diagenetic crystal growth.
Dimensions: Diameter $65-80 \mu \mathrm{m}$.

Occurrence: Sections 370-34-2 to 370-21-1.

Age: Barremian to Cenomanian/Turonian.

Pithonella longiporosa n. sp.

(Plate 2, Figures 1, 2; Plate 3, Figure 3)

Derivatio nominis: longiporosa (Latin): with elongated pores.

Holotype: Plate 2, Figures la, b, c.

Paratypes: Plate 2, Figures 2a-c; Figures 3a, b.

Type locality: DSDP Leg 41, Sample $370-21-1,23-25 \mathrm{~cm}$.

Type level: Latest Albian to Cenomanian.

Diagnosis: Test spherical, single-layered, penetrated by rounded and slit-like pores.

Description: Test spherical, consisting of one layer of about $5 \mu \mathrm{m}$ thickness. Crystals visible on the outer surface somewhat irregular between 1 and $5 \mu \mathrm{m}$ in diameter. The crystals are oriented randomly looking perpendicular to the outer surface or sometimes oblique like a pile. Their arrangement is closely packed. There are two types of pores visible on the outer surface: rounded ones with diameters up to $7 \mu \mathrm{m}$, and elongated, slit-like pores, up to $20 \mu \mathrm{m}$ in length and 2 to 3 $\mu \mathrm{m}$ in width. The elongated pores are arranged nearly at right angles to one another, like meridians and parallels although direct poles could not be detected. The distances between the rounded and the slit-like pores are nearly equal. In some cases, it looks like a meridional arrangement of the rounded pores in the same manner as shown by the slit-like pores. A prominent pore or aperture was not encountered.

Dimension of holotype: Diameter $78 \mu \mathrm{m}$.

Dimensions of paratypes: Diameter $65-75 \mu \mathrm{m}$

Occurrence: Sections 370-22-1 to 370-20-1.

Age: Uppermost Albian to Cenomanian/Turonian.

Remarks: Pithonella longiporosa differs from Pithonella porosa in its strongly elongated, slit-like pores.

\section{Pithonella amplicrystallina n. sp.}

(Plate 3, Figures 4-7)

Derivatio nominis: amplus (Latin): big, wide: crystallinus (Latin): crystalline.

Holotype: Plate 3, Figures 5a-c

Paratypes: Plate 3, Figures 4a-c, 6, 7a-d.

Type locality: DSDP Leg 41, Sample 369A-37-6, 43-45 cm

Type level: Maestrichtian.

Diagnosis: Test ovoidal, single-layered, composed of elongated calcite crystals with the long axis nearly parallel to the test surface.

Description: Test ovoidal, composed of a single layer of elongated calcite crystals, which are relatively loosely arranged with the long axis parallel or slightly oblique to the test surface. The thickness of the smallest diameters of the crystals is about $1 \mu \mathrm{m}$, the length about 4 $\mu \mathrm{m}$, the thickness of the wall is about $3 \mu \mathrm{m}$. An aperture is present in all investigated specimens. It is located symmetrically at one end of the test parallel to the longest axis. The diameter of the aperture varies between 15 and $20 \mu \mathrm{m}$. There are no significant differences in the wall structure around the aperture relative to other parts of the test.

Dimensions of holotype: Long axis $90 \mu \mathrm{m}$, diameter $68 \mu \mathrm{m}$.

Dimensions of paratypes: Long axis about 90 to $96 \mu \mathrm{m}$, diameter 68 to $72 \mu \mathrm{m}$.

Occurrence: $369 \mathrm{~A}-37-5$.

Age: Maestrichtian.

This species differs from Pithonella krasheninnikovi Bolli mainly by a larger size of the crystals forming the surface and the monolamellar wall. The inner layer of rough crystals apparent in Pithonella krasheninnikovi could not be detected. Pithonella veeversi is also elongated and single-layered, but its outer surface is built up of subtriangular crystals and its aperture is larger.

\section{Pithonella tuberculata n. sp.}

(Plate 1, Figures 7, 8)

Derivatio nominis: tuberculata (Latin): with tubercules.

Holotype: Plate 1, Figures 7a-c.

Paratype: Plate 4 , Figure 8 .

Type locality: DSDP Leg 41, Sample 370-43-3, 107-109 cm.

Type level: Late Valanginian to early Hauterivian.

Diagnosis: Test double-layered, subspherical, with single pores and big tubercules on the outer surface. 
Description: The subspherical tests show a very rough surface under the light microscope. Magnifications by SEM reveals a surface formed by small crystals of about 0.5 to $1 \mu \mathrm{m}$ in diameter. The rugosity is a result of big tubercules, composed of larger crystals arranged in piles. Single pores of 3 to $6 \mu \mathrm{m}$ in diameter are visible at the outer surface, but they have no special position. The wall is composed of at least two layers; the outer one is $1 \mu \mathrm{m}$ in thickness and is formed by oblique radially grown large crystals. The inner layer is built up of very small, randomly orientated, elongate crystals with diameters around 0.1 to $0.2 \mu \mathrm{m}$. The thickness of the inner layer is about $2 \mu \mathrm{m}$.

Dimensions of holotype: Diameter around $50 \mu \mathrm{m}$.

Occurrence: Sample 370-43-3, 107-109 cm, rare.

Age: Late Valanginian-early Hauterivian.

Remarks: This species is similar to Pithonella thayeri, but differs from that by the tubercules, the somewhat smaller crystals on the surface, and in having a multilayered wall. It differs from Pithonella guttula $\mathrm{n}$. sp. by having tubercules and in its globular outline.

Pithonella trilamellata n. sp.

(Plate 6, Figures 3-5, 7; Plate 7, Figures 1, 2)

Derivatio nominis: trilamellata (Latin): three-layered.

Holotype: Plate 6, Figures 3a-c.

Paratypes: Plate 6, Figures 4, 5, 7 .

Type locality: DSDP Leg 41, Sample 370-33, CC.

Type level: Barremian to Aptian.

Diagnosis: Test globular, consisting of three main calcite layers, the outermost consisting of plate-like crystals, the intermediate one is composed of randomly oriented stick-like crystals, and the innermost layer is built up of randomly oriented, stick-like, fine crystals.

Description: Test globular to slightly ovoidal, consisting of three main layers. The outermost layer is 3 to $4 \mu \mathrm{m}$ in thickness and is formed by large crystals of up to $10 \mu \mathrm{m}$ in diameter at the outer surface. The surface of the crystals is plate-like so that the outer surface of the test looks like a pavement. The thickness of the intermediate layer reaches up to $4 \mu \mathrm{m}$. There is a transition to another type of crystals at the base of the outer layer which have diameters of $1 \mu \mathrm{m}$ and which are oriented oblique to the radius. They are arranged crosswise at different angles with empty interspaces between them. The base of the medium layer is formed by a lining, probably of organic matter (Plate 7, Figure 2). The surface of the inner layer is sometimes difficult to detect. The outer surface of the inner layer is seen as a polished cutting of randomly oriented and relatively loosely packed, very fine crystals where corrosion has removed this coating. The diameter of these crystals is 0.2 to $0.5 \mu \mathrm{m}$. The thickness of the inner layer is about $5 \mu \mathrm{m}$.

Single, large, well-rounded apertures are present, but not visible in all specimens.

Dimensions of holotype: Diameter $80 \mu \mathrm{m}$.

Dimensions of paratypes: Diameter 50 to $80 \mu \mathrm{m}$.

Occurrence: DSDP Leg 41, Samples $370-46-2,34-36 \mathrm{~cm}$, to 370 33, CC.

Age: Valanginian to Barremian, and possibly ? Aptian-Albian.

Remarks: Pithonella trilamellata $\mathrm{n}$. $\mathrm{sp}$. strongly resembles the three-layered Pithonella helentappanae Bolli from the Albian off northwest Australia. Differences are given in the thickness of the innermost layer, which in Pithonella trilamellata $\mathrm{n}$. $\mathrm{sp}$. is nearly the same as the outer layer, whereas in Pithonella helentappanae the inner layer is very thin. The characteristic outermost test surface of Pithonella trilamellata $\mathrm{n}$. sp. cannot be seen in the figures given by Bolli (1974) for Pithonella helentappanae.

Our species is quite similar to Pithonella multistrata n. sp., but in the latter the outermost layer is missing and the boundary between the intermediate and inner layer is more pronounced by different crystal sizes in $P$. trilamellata. In some cases, only the innermost layer is represented. These specimens have a very glassy surface under the light microscope. They resemble to some degree Pithonella patriciagreeleyae Bolli, but in the cross-section figured by Bolli (1974) the latter species has thicker and more compacted crystals.

\section{Pithonella multistrata n. sp.}

(Plate 7, Figures 3-6)

Derivatio nominis: multistrata (Latin): composed of many layers.

Holotype: Plate 7, Figures 3a-f.

Paratypes: Plate 7, Figures 4a, b, 5a, b, 6a, b.

Type locality: DSDP Leg 41, Sample 370-43-3, 107-109 cm.
Type level: Valanginian to Hauterivian.

Diagnosis: Test globular, wall consisting of several different calcite layers, separated by organic linings. Outer layer coarsely crystalline, crystals oriented oblique radially, inner layer finely crystalline, crystals randomly grown.

Description: Test globular, consisting of several layers. The outer surface is formed by crystals which are arranged like a pavement with some interspaces. The crystal size, as seen from the outer surface, is around $2 \mu \mathrm{m}$, but smaller crystals of around $1 \mu \mathrm{m}$ also exist as do more rarely, larger ones with diameters up to $6 \mu \mathrm{m}$. The latter are distributed in irregular patterns across the outer surface. The surface has a mat appearance under the light microscope. The outer layer is about $7 \mu \mathrm{m}$ in thickness. The crystals are loosely arranged and oriented crosswise oblique to the radius of the test. The angle between the crystals is about $60^{\circ}$. Sometimes a very thin coating which can easily be removed at the outer surface is observed. It is considered to be the residual of an outermost layer, similar to that of Pithonella trilamellata $\mathrm{n}$. sp.

The outer layer can be divided using crystal diameters into an outer part with diameters of around $1 \mu \mathrm{m}$, and an inner part of $1 \mu \mathrm{m}$ in thickness where the crystals have diameters below $0.2 \mu \mathrm{m}$. The inner surface of the outer layer is smooth. The boundary between these two parts is not sharp, but rather the different crystals are intermingled. A residual of a thin lining of possibly organic matter was found between the outer layer and the inner layer. The outer surface of the inner layer has the same outline as the inner surface of the outer layer.

The inner layer is about 7 to $8 \mu \mathrm{m}$ in thickness and composed of irregularly arranged crystals of $0.2 \mu \mathrm{m}$ in diameter and up to $1 \mu \mathrm{m}$ in length. The inner surface of the inner layer is only partly visible and has a structure similar to the cross-section. The inner layer to the interior is covered by a flexible lining which shows no structures at high magnifications under the SEM. It is believed to be organic matter. An aperture of about $20 \mu \mathrm{m}$ diameter has been observed in some specimens.

Dimensions: Diameter 40 to $70 \mu \mathrm{m}$.

Occurrence: Sections 370-43-3, 370-34-2, (?) 370-48-1, rare.

Age: Valanginian to Barremian.

Taxonomy: The outer surface and the cross-section of the outer layer are very similar to those of Pithonella johnstonei Bolli (1974, pl. 6 , fig. $5,6,8)$ from the Senonian, but the crossing angle of crystals in Pithonella multistrata is around $60^{\circ}$, not $90^{\circ}$ as in Pithonella johnstonei. Additionally, Pithonella johnstonei is described as a singlelayered form without an inner lining. Pithonella quiltyi from the Albian is also closely related, but an inner lining was not described by Bolli (1974).

Pithonella guttula n. sp.

(Plate 8, Figures 1-4)

Derivatio nominis: guttula (Latin): small drop.

Holotype: Plate 8, Figures la-e.

Paratypes: Plate 8, Figures 2-4.

Type locality: DSDP Leg 41, Sample 370-40-1, 39-41 cm.

Type level: Valanginian to Hauterivian.

Diagnosis: Test ovoidal, wall consisting of several layers; the outer one formed by big plate-like crystals and the intermediate layer is composed of finer crystals, oblique radially oriented with a sharp boundary with the innermost layer. The inner layer is composed of randomly oriented, fine, needle-like crystals.

Description: Test generally subspherical to drop-like. Some specimens have been distinguished with a knob-like protrusion at one pole, but without a visible aperture. The surface structure in that region is not different from that of other parts of the test. The wall consists of several layers. The outer surface is formed by irregularly distributed crystals of various sizes between 4 and $16 \mu \mathrm{m}$ in diameter on the surface. As seen in cross-section, the outer layer is about $7 \mu \mathrm{m}$ in thickness with large crystals oriented oblique to the radius. Below these big plate-like crystals, there are smaller ones of more stick-like outline also oriented oblique to the radius and arranged in pile structures. The boundary between the large crystals and the smaller ones is transitional, whereas the boundary with the inner layer is sharply marked by an even layer of a thickness too small to measure. Because there are no structures visible at high SEM magnifications, this layer is believed to be organic matter. Below this lining there is the inner layer formed by loosely arranged, needle- to plate-like crystals with diameters of about $0.2 \mu \mathrm{m}$ and lengths up to $3 \mu \mathrm{m}$. Their orientation is random (Plate 8 , Figures $1 \mathrm{~b}, \mathrm{c}$ ). The thickness of the 
inner layer is more than $5 \mu \mathrm{m}$, but we have not yet recorded a good section through the inner layer.

The big crystals at the outer surface are isolated and the spaces between them are open or filled by smaller crystals, sometimes of more stick-like shape. Although the outer surface is composed of quite large components, its general surface is smooth, like a loosely arranged pavement.

Dimension of holotype: Length $88 \mu \mathrm{m}$, diameter $72 \mu \mathrm{m}$.

Dimension of paratypes: Length 85 to $97 \mu \mathrm{m}$, diameter 67 to 82 $\mu \mathrm{m}$.

Occurrence: Sample 370-45, CC to Section 370-40-1.

Age: Valanginian to Hauterivian.

Remarks: Pithonella guttula n. sp. differs from Pithonella trilamellata $\mathrm{n} . \mathrm{sp}$, in its ovoidal (not spherical) outline and in its finer crystalline innermost layer. Pithonella multistrata n, sp. lacks the coarse crystalline outer layer and is globose, not drop-like.

\section{Pithonella krasheninnikovi Bolli}

(Plate 4, Figures 1-6)

02

Pithonella krasheninnikovi Bolli, 1974, p. 856, pl. 7, fig. 1-5, pl. 18 , fig. $10-12$, pl. 19 , fig. $1-12$, pl. 20 , fig. $1-4$, pl. 24 , fig. 1 , 2 .

Description: Test ovoidal, consisting of two layers. The outer layer ( 2 to $5 \mu \mathrm{m}$ in thickness) is formed by irregularly arranged small crystals with the longest axis parallel or slightly oblique to the outer surface. The smallest diameters are around 0.8 to $1.2 \mu \mathrm{m}$. Externally, the crystals are clearly separated from each other with straight edges. Their sizes range 0.6 to $1 \times 1.6 \times 3$ to $4 \mu \mathrm{m}$. Some larger crystals of 1.6 to $2.6 \mu \mathrm{m}$ in diameter may occur in the outer layer. A somewhat porous surface is given by the loosely arranged small crystals.

The inner layer is about $6 \mu \mathrm{m}$ in thickness and consists of heavy crystals. The aperture is positioned a bit asymmetrically at one end, its size varies between 20 and $35 \mu \mathrm{m}$ in diameter. Occasionally, it is surrounded by thick crystals of the inner layer. In tiose cases, the outer layer may have been partly removed. We encountered specimens in some samples whose outer layer was partly or totally removed.

Pithonella krasheninnikovi has been described as distinctly elongate with a width/length ratio of approximately 1:2. Variability of our specimens is between 1:2 and 1:1.2.

Dimensions: Length up to $110 \mu \mathrm{m}$, thickness: around $60 \mu \mathrm{m}$.

Occurrence: Sections 369A-38-5 to 369A-37-4.

Age: Campanian to early Maestrichtian.

Remarks: Pithonella krasheninnikovi differs from Pithonello bilamellata $\mathrm{n}$. sp. in the more elongated shape of the test and in the more tangentially oriented crystals of the outer layer. Pithonella mcknighti has a similar surface, but coarser crystals, and is singlelayered. Pithonella robinsoni is double-layered and ovoidal like Pithonella krasheninnikovi, but the outer layer is composed of two different crystal types. Pithonella edgari is double-layered as well, but the inner layer is composed of crystals with shape and arrangement similar to the outer layer, and not of heavy crystals like those of Pithonella krasheninnikovi.

Pithonella krasheninnikovi was initially described by Bolli (1974) from the Upper Cretaceous, probably Coniacian to Santonian, from DSDP Leg 27 Site 260 in the Eastern Indian Ocean off northwest Australia. Its range is now extended to include early Maestrichtian.

\section{Pithonella cylindrica n. sp.}

(Plate 5, Figures 1-4)

Derivatio nominis: cylindrus (Latin): cylinder.

Holotype: Plate 5, Figures 4a-c.

Paratypes: Plate 5, Figures 1-3.

Type locality: DSDP Leg 41, Sample 369A-37-4, 63-65 cm

Type level: Campanian to Maestrichtian.

Diagnosis: Test elongated ovoidal with nearly cylindrical flanges, composed of two layers of crystals; the outer formed by oblique tangentially arranged small crystals, and the inner layer composed of densely packed large crystals.

Description: Test of elongated shape, the flanges being nearly cylindrical and the poles subspherical. The wall is built up of two layers. The outer layer consists of small crystals, the longest axis of which are oriented oblique tangentially to the surface. The smaller diameters of the plate-like crystals are between 0.6 and $1.6 \mu \mathrm{m}$. The longest diameters are about $2 \mu \mathrm{m}$. The thickness of the outer layer is about $2 \mu \mathrm{m}$.
The inner layer is composed of one layer of large, densely packed euhedral crystals, radially oriented. The inner layer is about 3 to $4 \mu \mathrm{m}$ in thickness. An aperture is asymmetrically positioned at one pole.

Dimensions of holotype: Length $100 \mu \mathrm{m}$, diameter $62 \mu \mathrm{m}$.

Dimensions of paratypes: Length 96 to $108 \mu \mathrm{m}$, diameter 60 to 64 $\mu \mathrm{m}$.

Occurrence: DSDP Leg 41, Samples 369A-37-4, 63-65 cm, 369A$37-5,63-65 \mathrm{~cm}$.

Age: Campanian to Maestrichtian.

Remarks: Pithonella cylindrica n. sp. is distinguished from Pithonella krasheninnikovi by its elongated shape with nearly cylindrical flanges, whereas Pithonella krasheninnikovi has a more spindle-like outline.

Pithonella bilamellata $n$. sp. (Plate 5, Figures 5, 6; Plate 6, Figures 1, 2)

Derivatio nominis: bi (Latin): double, lamellata (Latin): layered. Holotype: Plate 5, Figures 6a-d.

Paratypes: Plate 5, Figure 5; Plate 6, Figures 1, 2.

Type locality: DSDP Leg 4I, Sample 369A-36-3, $23-25 \mathrm{~cm}$.

Type level: Early Maestrichtian.

Diagnosis: Test ovoidal, consisting of two layers, the outer formed by oblique radially oriented, small crystals, the inner formed by densely packed, large crystals, radially oriented.

Description: Test ovoidal, consisting of two layers of calcite crystals. The outer layer is composed of short, somewhat irregularly radially arranged crystals which tend to have an oblique position. They are clearly separated from each other, sometimes with interspaces, producing a pseudoporous surface. The short diameters of the crystals are around $0.8 \mu \mathrm{m}$, and their longest axis is about $2 \mu \mathrm{m}$, which is also the thickness of the outer layer.

The thickness of the inner layer is up to $8 \mu \mathrm{m}$. The inner layer is formed by heavy, densely packed, radially arranged, crystals. The boundary between the two layers is sharp. Sometimes the outer layer is partly removed.

A wide opening with irregular borders at one end may be an aperture.

Dimensions of holotype: Length $104 \mu \mathrm{m}$, diameter $68 \mu \mathrm{m}$.

Dimensions of paratypes: Length up to $110 \mu \mathrm{m}$, diameter 60 to 64 $\mu \mathrm{m}$.

Occurrence: DSDP Leg 41, Hole 369A, Sections 38-2 to 36-3.

Age: Upper Cretaceous, Campanian to Maestrichtian.

Lithology of the samples: Nanno-bearing marl and nannomarlstone.

Remarks: Pithonella bilamellata $\mathrm{n}$. sp. differs from $P$. krasheninnikovi in having a more shortened oval shape, and in more radially arranged crystals of the outer layer. $P$. robinsoni has an outer layer consisting of two different crystal types, which we have not encountered in the new species. The inner layer in $P$. edgari is not as coarsely crystalline as in $P$. bilamellata $\mathrm{n}$. sp.

Pithonella sp. 2

(Plate 8, Figure 5)

Description: Test globular to slightly ovoidal. The outer surface shows a pavement-like structure. Crystals of about 4 to $10 \mu \mathrm{m}$ in diameter are intermixed with some smaller ones to form an irregularly polygonal pattern. The texture of the surface is rather even, although the edges of the crystals have holes producing a somewhat porous outline in the SEM views. Distinct apertures were not found. The species is given in open nomenclature. because we do not know the precise structure of the wall. It may be a variant of Pithonella trilamellata.

Dimensions: Diameter 65 to $95 \mu \mathrm{m}$.

Occurrence: DSDP Leg 41, Samples 370-44-1, 71-73 cm and 370. $34-2,73-75 \mathrm{~cm}$, rare.

Age: Valanginian to Barremian.

Remarks: The range falls in the range of Pithonella trilamellata. We found some other specimens with very smooth surfaces (compare Plate 8, Figure 6). Identification is difficult because these forms may be only parts of specimens with the outer layers removed.

\section{ACKNOWLEDGMENTS}

We wish to acknowledge the Deep Sea Drilling Project for providing the opportunity to participate on Leg 41 of Glomar Challenger and the Geological Institute of the Academy of 
Sciences of the USSR and the Geological-Paleontological Institute of the Kiel University for leave.

Technical help included that from Mrs. C. Schulz, Mr. W. Reimann, and Mr. W. Rösler. The English text was revised by J. Gardner.

This contribution was supported by Deutsche Forschungsgemeinschaft (German research society).

\section{REFERENCES}

Banner, F.T., 1972. Pithonella ovalis from the early Cenomanian of England: Micropaleontology, v. 18, p. 278.

Bein, A. and Reiss, Z., 1976. Cretaceous Pithonella from Israel: Micropaleontology, v. 22, p. 83.

Bolli, H.M., 1974. Jurassic and Cretaceous Calcisphaerulidae from DSDP Leg 27, Eastern Indian Ocean. In Veevers,
J.J., Heirtzler, J.R., et al., Initial Reports of the Deep Sea Drilling Project, Volume 27: Washington (U.S. Government Printing Office), p. 843.

Villain, J.-M., 1975. "Calcisphaerulidae" (incertae sedis) du Cretacé superieur du Limbourg (Pays-Bas), et d'autre regions: Palaeontogr., A, v. 149 , p. 193.

Wiedmann, J., 1975. Faunenprovinzen der westmediterranen Kreide: Abstracts of papers, Paläont. Ges. 45. Jahresversamml. Hannover.

\section{EXPLANATIONS TO PLATES}

Figures with the same number but different letters belong to the same specimen. Following the magnification is the gun potential and the number of the scanning electron microscope photograph. 


\section{PLATE 1}

Figure $1 \quad$ Pithonella thayeri Bolli.

Sample 41-370-35-5, $27-29 \mathrm{~cm}$.

1a. Lateral view, showing the irregular distribution of subrounded large and small crystals. $\times 500,20 \mathrm{kv}$, No. 53003 .

1b. Detail of the surface from the central part of Figure 1a; note the pseudopores. $\times 2500,20 \mathrm{kv}$, No. 53004 .

Figure 2 Pithonella thayeri Bolli.

Sample 41-370-24-5, 73-75 cm.

2a. Lateral view, showing pustule-like engrown large crystals between smaller ones with plate-like surfaces. $\times 500,20 \mathrm{kv}$, No. 53308 .

2b. Detail of the surface. The surface is smooth between the large crystals and may be an artificial coating of gelatine during mounting procedure. $\times 2500,20 \mathrm{kv}$, No.52309.

Figure 3 Pithonella thayeri ?Bolli.

Sample 41-370-35-5, 27-29 cm.

3a. Apertural view of a specimen, which may be $P$. thayeri. The aperture is surrounded by small crystals. $\times 500,20 \mathrm{kv}$, No. 52990 .

$3 \mathrm{~b}$. Detail of the lateral outer surface, showing irregularly shaped porelike openings between crystals of different sizes. $\times 2500,20 \mathrm{kv}$, No. 52991.

Figure $4 \quad$ Pithonella thayeri Bolli.

Sample 41-370-35-5, 27-29 cm.

4a. Lateral view to a specimen with partly removed wall. $\times 500,20 \mathrm{kv}$, No. 52998.

4b. Detail of the broken wall, large crystals are partly grown on very small ones. The ultrastructure of the surface of the filling is a negative of the inner surface of the wall, but could not be resolved at higher SEM magnifications. $\times 2500,20 \mathrm{kv}$, No. 53000 .

Figure 5

Pithonella thayeri Bolli.

Sample 41-370-34-2, 73-75 cm.

5a. Lateral view of a specimen with very large plate-like crystals irregularly distributed. $\times 500,20 \mathrm{kv}$, No. 53656 .

5 b. Detail of the surface with signs of corrosion. Note the small holes on the big crystals. $\times 2500,10 \mathrm{kv}$, No. 53655 .

Figure $6 \quad$ Pithonella sp. 1.

Sample 41-370-34-2, 73-75 cm.

6a. Specimen with oblique and irregularly imbricated large crystals at the surface. $\times 500,10 \mathrm{kv}$, No. 53671 .

6b. Detail of the outer surface, with twin crystallization. $\times 2500,10 \mathrm{kv}$, No. 53670 .

Figure 7 Pithonella tuberculata n. sp. (holotype).

Sample 41-370-43-3, 107-109 cm.

7a. Lateral view. The holes are enlarged due to corrosion. $\times 500,10 \mathrm{kv}$, No. 53746.

7b. Detail of the outer surface. The wall is multilayered. To the lower right of the hole, the outer portion of the intermediate crystalline layer is removed, showing a fine crystalline surface of the inner layer. $\times 2500,10 \mathrm{kv}$, No. 53747 .

7c. Detail of some pustules formed by an agglomeration of large crystals, smoothly textured similar to the outer surface of the area between the pustules. $\times 2500,10 \mathrm{kv}$, No. 53748 .

Figure $8 \quad$ Pithonella tuberculata n. sp. Sample 41-370-43-3, 107-109 cm.

Lateral view to a paratype. $\times 500,10 \mathrm{kv}$, No. 53749 . 

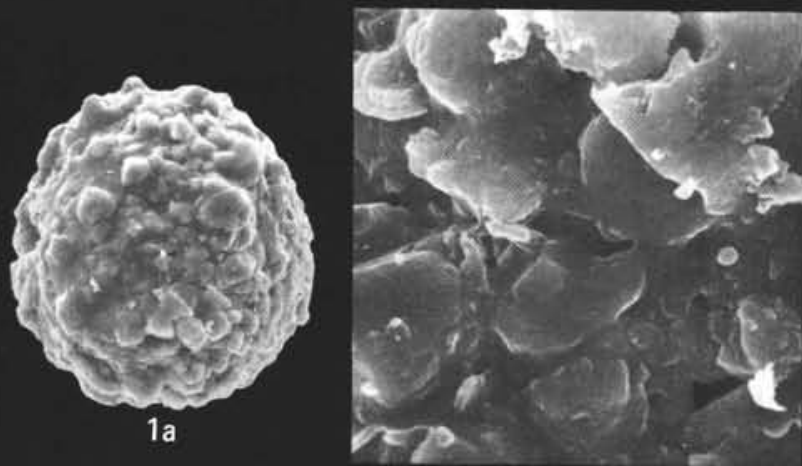

$1 \mathrm{~b}$
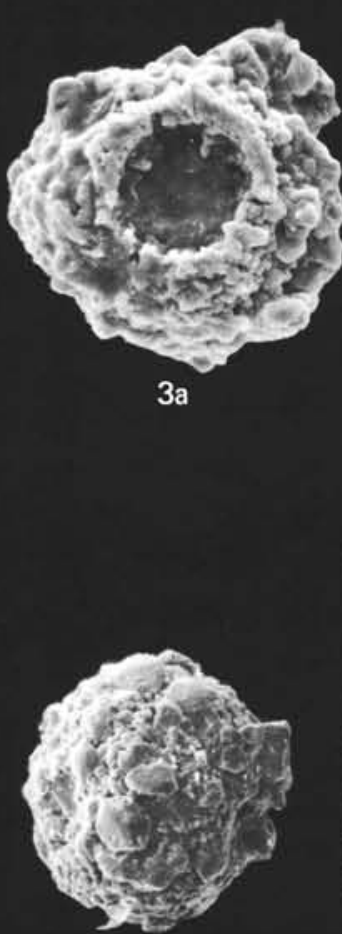

$5 a$

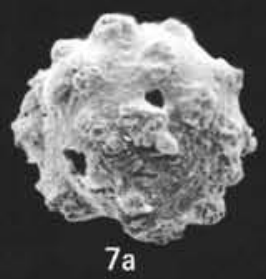

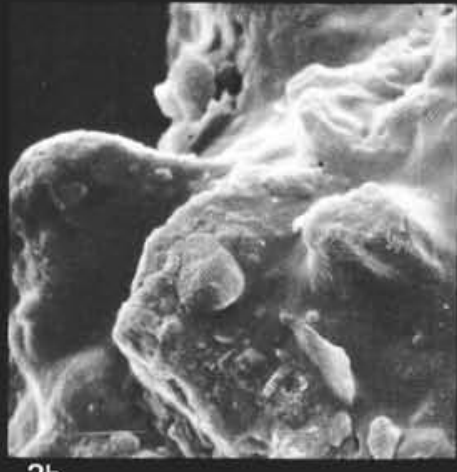

$2 \mathrm{~b}$

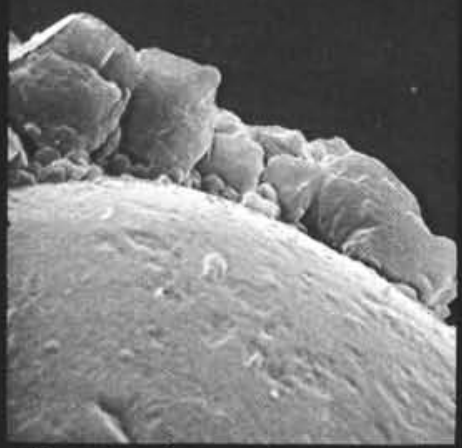

$4 b$

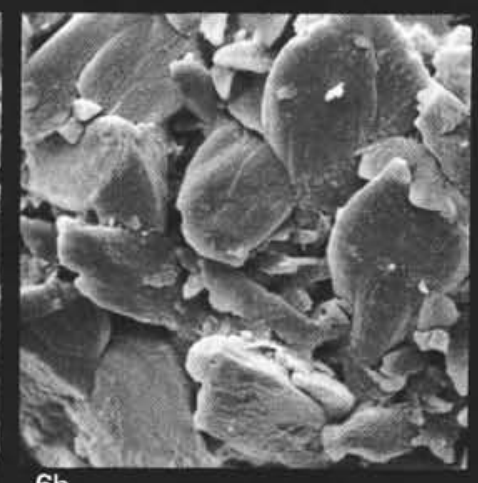

$6 b$

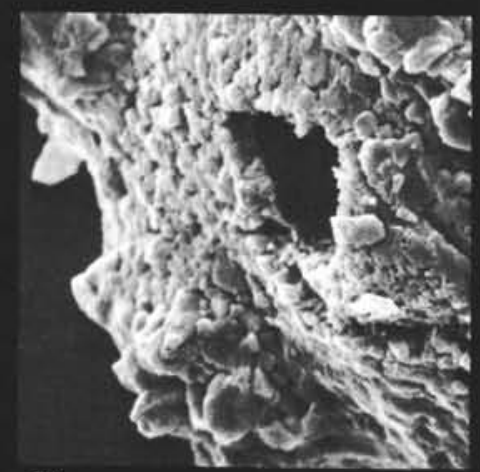

$7 b$

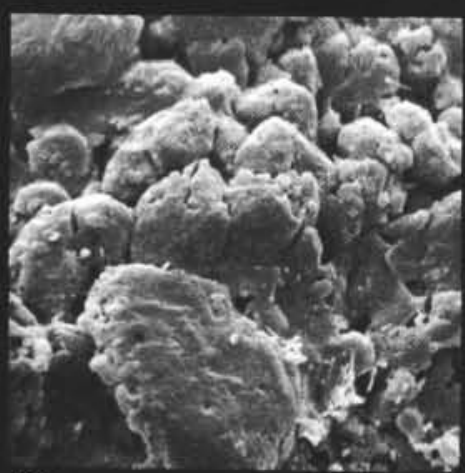

$5 b$

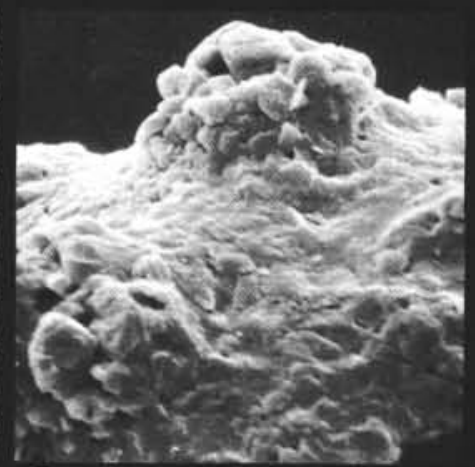

$7 c$
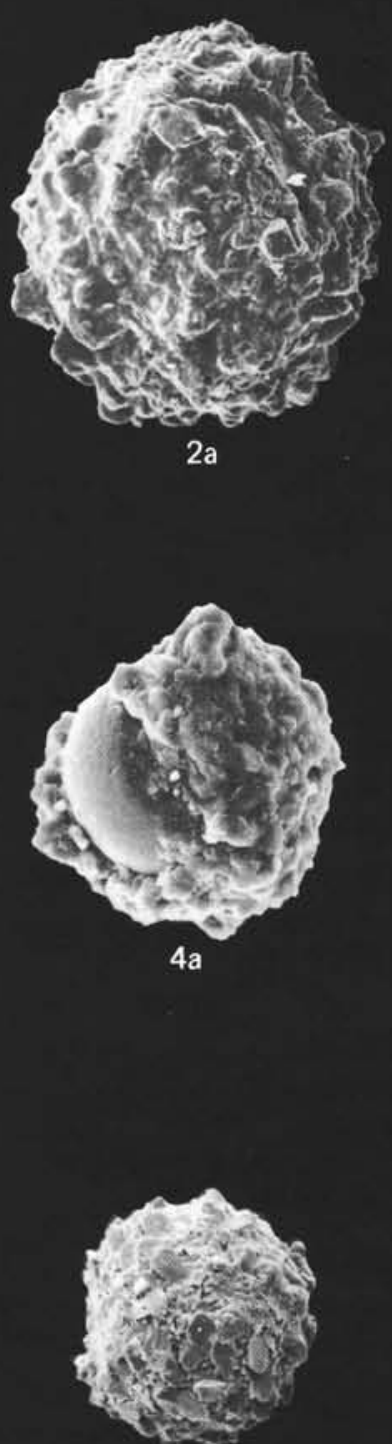

$6 a$

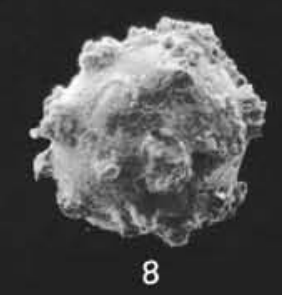




\section{PLATE 2}

Figure 1 Pithonella longiporosa $\mathrm{n}$. sp. (holotype).

Sample 41-370-21-1, 23-25 cm.

la, 1c. View from different sides of the same test, angle between the views $77^{\circ}$. The slit-like pores and the connecting lines between the rounded ones cross each other at nearly right angles. $\times 500,10 \mathrm{kv}$, (a) No. 53538, (c) No. 53549.

1b. Detail of the outer surface. The crystals show very irregular edges and holes which may be due to corrosion of the outermost layer. The crystal size is larger around the pores and the orientation is at nearly right angles to the pore margin (lower left). $\times 2500,10 \mathrm{kv}$, No. 53539 .

Figure 2 Pithonella longiporosa n. sp.

Sample 41-370-21-1, 23-25 cm.

2a. Artificially broken specimen. $\times 500,10 \mathrm{kv}$, No. 53530 .

2b. View to the broken wall, showing a monolamellar layer of irregularly oblique-oriented crystals. $\times 2500,10 \mathrm{kv}$, No. 53533 .

2c. View of the inner surface of the wall showing the smooth fine crystals. The arrangement of crystals around the pores is not typical. $\times 2500,10 \mathrm{kv}$, No. 53531 .

Figure 3 Pithonella longiporosa $\mathrm{n}$. sp.

Sample 41-370-21-1, 23-25 cm.

3a. Lateral view of a specimen looking at a break, not aperture. $\times 500$. $10 \mathrm{kv}$, No. 53540.

3b. Cross-break of the wall, showing the single layer of more or less radially oriented crystals. $\times 2500,10 \mathrm{kv}$, No. 53541 .

Figure 4 Pithonella porosa n. sp. (holotype).

Sample 41-370-24-5, 73-75 cm.

4a. Peripheral view showing a large opening and narrow slit-like rounded pores. $\times 500,20 \mathrm{kv}$, No. 53012 .

4b. Transverse section of the wall showing a single layer of oriented crystals. $\times 2500,20 \mathrm{kv}$, No. 53013 .

Figure $5 \quad$ Pithonella porosa $\mathrm{n}$. sp.

Sample 41-370-23-1, 93-95 cm.

5a. Artificially broken specimen showing the inner surface and the wall structure. A marcasite crystal is attached at the upper left. $\times 500,10$ kv, No. 53715 .

5b. Cross-section of the monolamellar wall. The more or less radially oriented crystals have increasingly larger diameters toward the outer surface. Compare Figure 5c. $\times 2500,10 \mathrm{kv}$, No. 53716.

5c. Detail of the inner surface. The diameters of the crystals in that view are nearly equal, the pores are partly closed by large engrown crystals. $\times 2500,10 \mathrm{kv}$, No. 53717 .

Figure $6 \quad$ Pithonella porosa $\mathrm{n}$. sp.

Sample 41-370-22-1, 73-75 cm.

6a. Lateral view. $\times 500,10 \mathrm{kv}$, No. 53731 .

6b. Detail of the outer surface around an elongated pore. $\times 2500,10 \mathrm{kv}$, No. 53732.

Figure $7 \quad$ Pithonella porosa $\mathrm{n}$. sp.

Sample 41-370-20-1, 73-75 cm.

Lateral view to a specimen with a circular main aperture. $\times 500,10 \mathrm{kv}$, No. 52401. 
PLATE 2
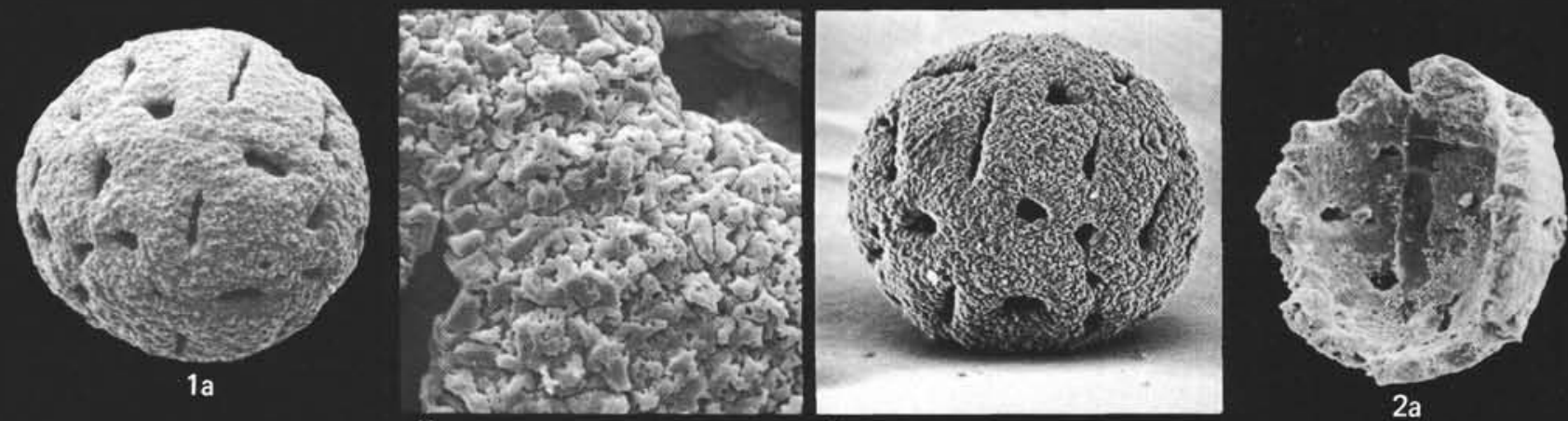

$1 c$
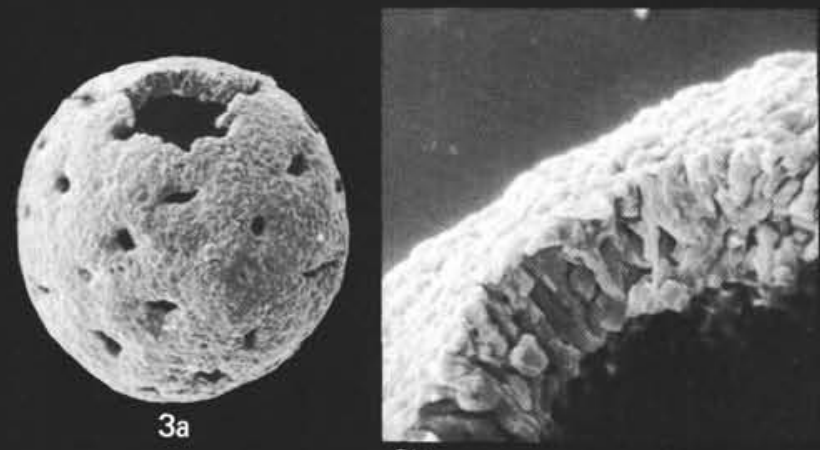

$3 b$

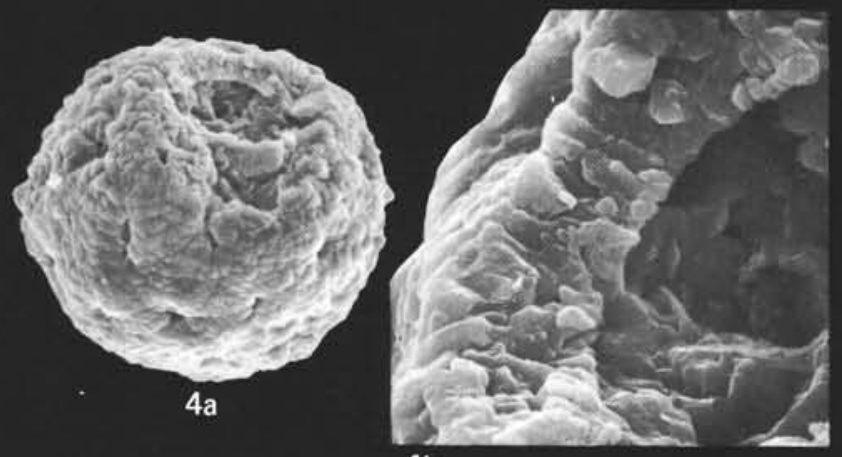

$4 b$

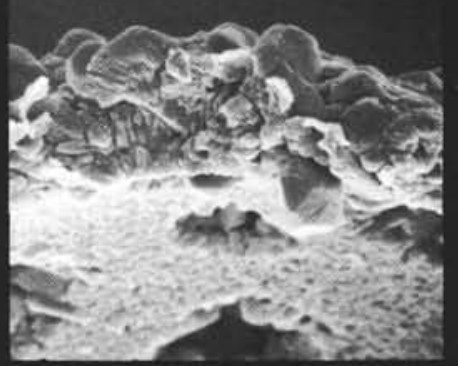

$5 b$
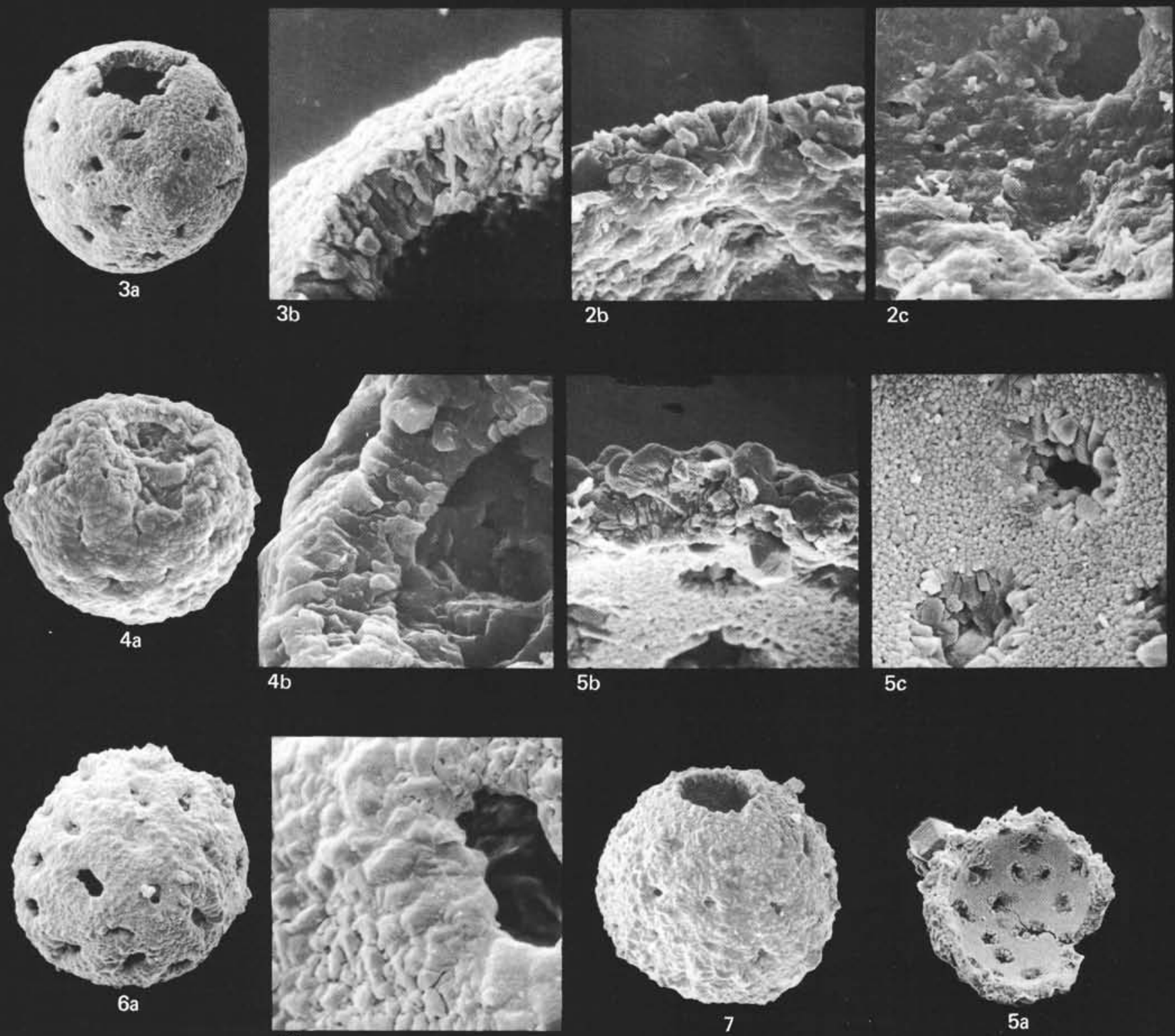


\section{PLATE 3}

Figure 1

Figure 2

Figure 3

Figure 4

Figure 6

Figure 7
Pithonella porosa $\mathrm{n}$. sp. forma obturata $\mathrm{n}$. forma. Sample 41-370-21-2, 63-65 cm.

la. View of a specimen with very small pores. The distances between the pores are nearly the same as those in Figure 1b. $\times 500,10 \mathrm{kv}$. No. 53518 .

Ib. Detail of the outer surface showing the irregular arranged large and small crystals, without any special arrangement in the vicinity of the pores. $\times 2500,10 \mathrm{kv}$, No. 53517.

Pithonella porosa $\mathrm{n}$. sp. forma obturata $\mathrm{n}$. forma. Sample 41-370-22-1, 73-75 cm.

2 a. Lateral view without visible pores. $\times 500,10$ kv, No. 52725 .

2b. Detail of the outer surface with cobblestone crystals of different sizes. $\times 2500,10 \mathrm{kv}$, No. 52726 .

Pithonella porosa $\mathrm{n}$. sp. forma obturata $\mathrm{n}$. forma. Sample 41-370-22-1, 73-75 cm.

Detail of a broken specimen, showing the monolamellar wall structure and the fine crystalline inner surface of the wall. $\times 2500,10 \mathrm{kv}$, No. 53736 .

Pithonella amplicrystallina $\mathrm{n}$. $\mathrm{sp}$. Sample 41-369A-37-6, 43-45 cm.

4a. Lateral view. $\times 500,20 \mathrm{kv}$, No. 53257.

4b. Detail of the apertural region. $\times 2500,20 \mathrm{kv}$, No. 53258.

4c. Distal view. $\times 500,20 \mathrm{kv}$, No. 53257 .

Pithonella amplicrystallina $\mathrm{n}$. sp. (holotype). Sample 41-369A-37-5, 43-45 cm.

5a. Lateral view. $\times 500,20 \mathrm{kv}$, No. 53249 .

5 b. Oblique view to the apertural area, with a monolamellar wall. $\times 2500,20 \mathrm{kv}$, No. 53250.

5c. Detail of the lateral outer surface. $\times 2500,20$ kv, No. 53248.

Pithonella amplicrystallina $\mathrm{n}$. $\mathrm{sp}$.

Sample 41-369A-37-6, 43-45 cm.

Detail of the lateral outer surface showing the nearly equal size of the crystals as occurs in Figure 5c. $\times 2500,20 \mathrm{kv}$, No. 53239 .

Pithonella amplicrystallina $\mathrm{n}$. $\mathrm{sp}$.

Sample 41-369A-37-5, 63-65 cm.

7a. Lateral view. $\times 500,20 \mathrm{kv}$, No. 53195 .

7b. Detail of the lateral outer surface. $\times 2500,20$ kv, No. 53194.

7c. Detail of the monolamellar wall at the distal end. $\times 2500,20 \mathrm{kv}$, No. 53196 .

7d. Distal view. The aperture is enlarged by fragmentation. $\times 500,20 \mathrm{kv}$, No. 53208 . 
PLATE 3
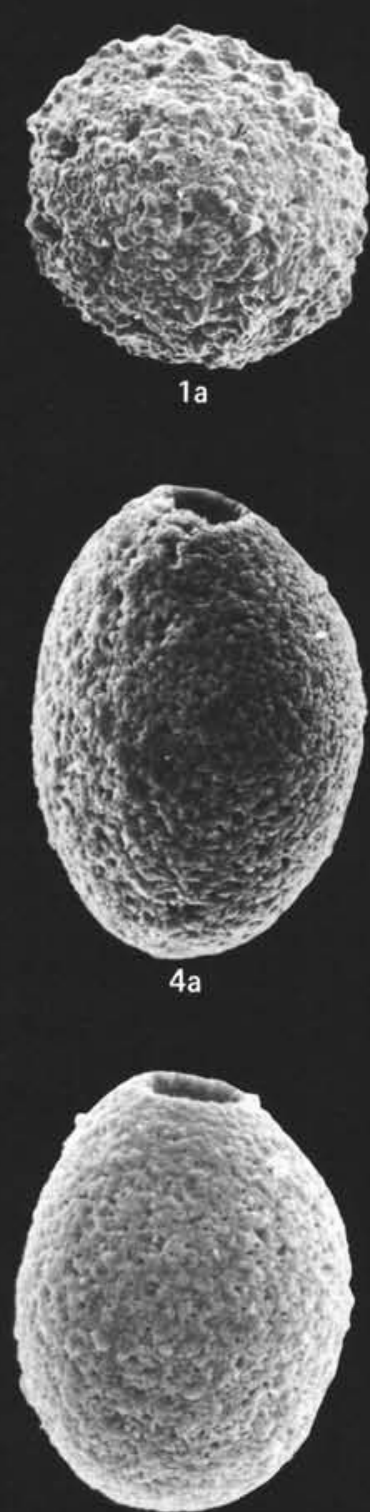

$5 a$

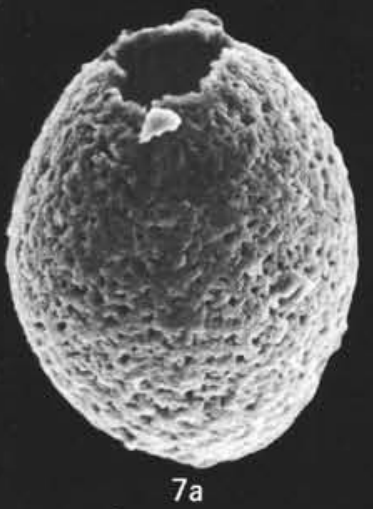

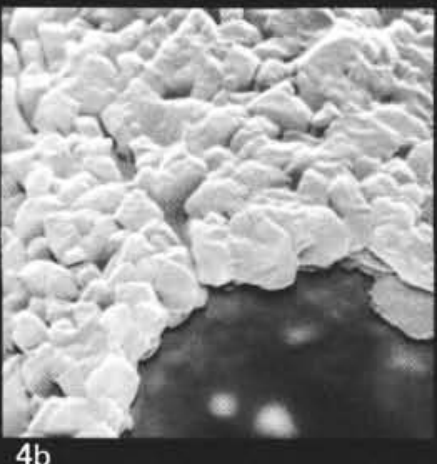

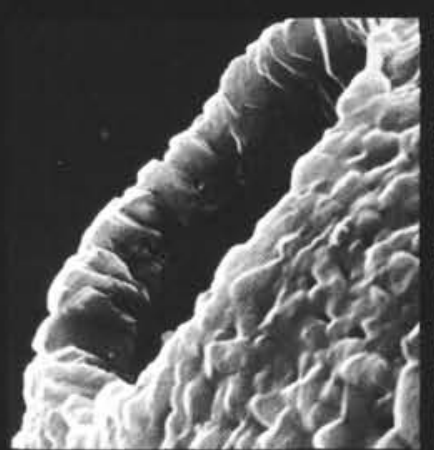

$5 b$

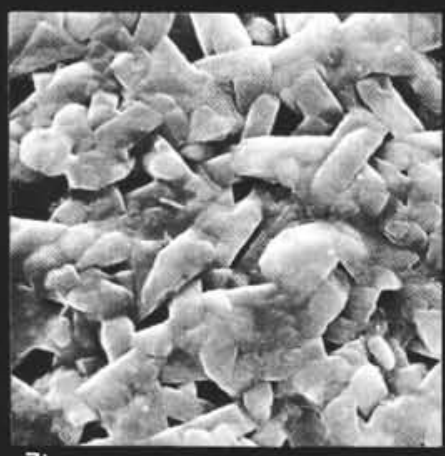

$7 b$

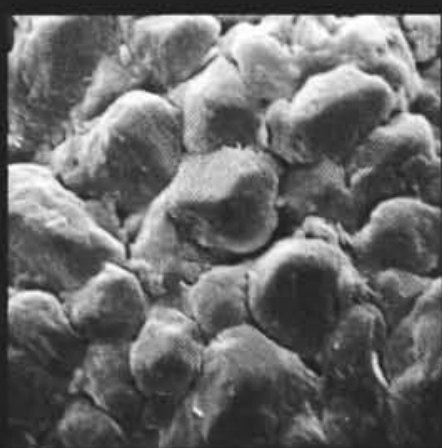

$2 b$
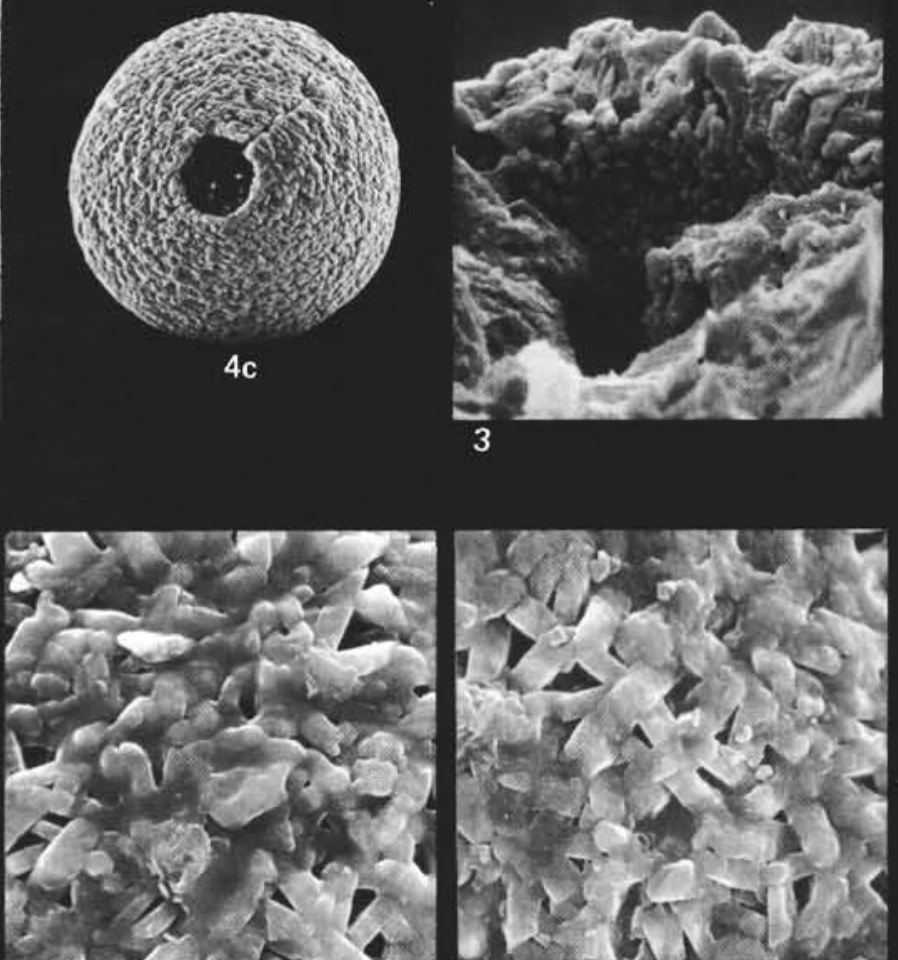

$5 c$

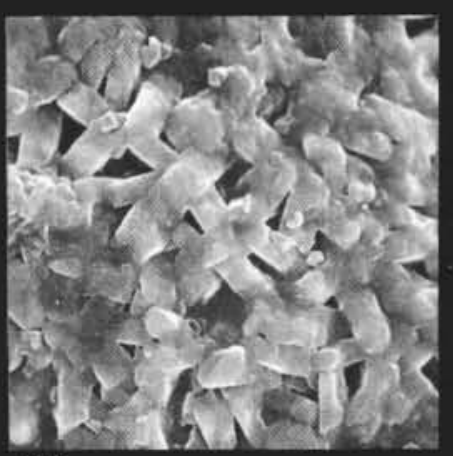

5d
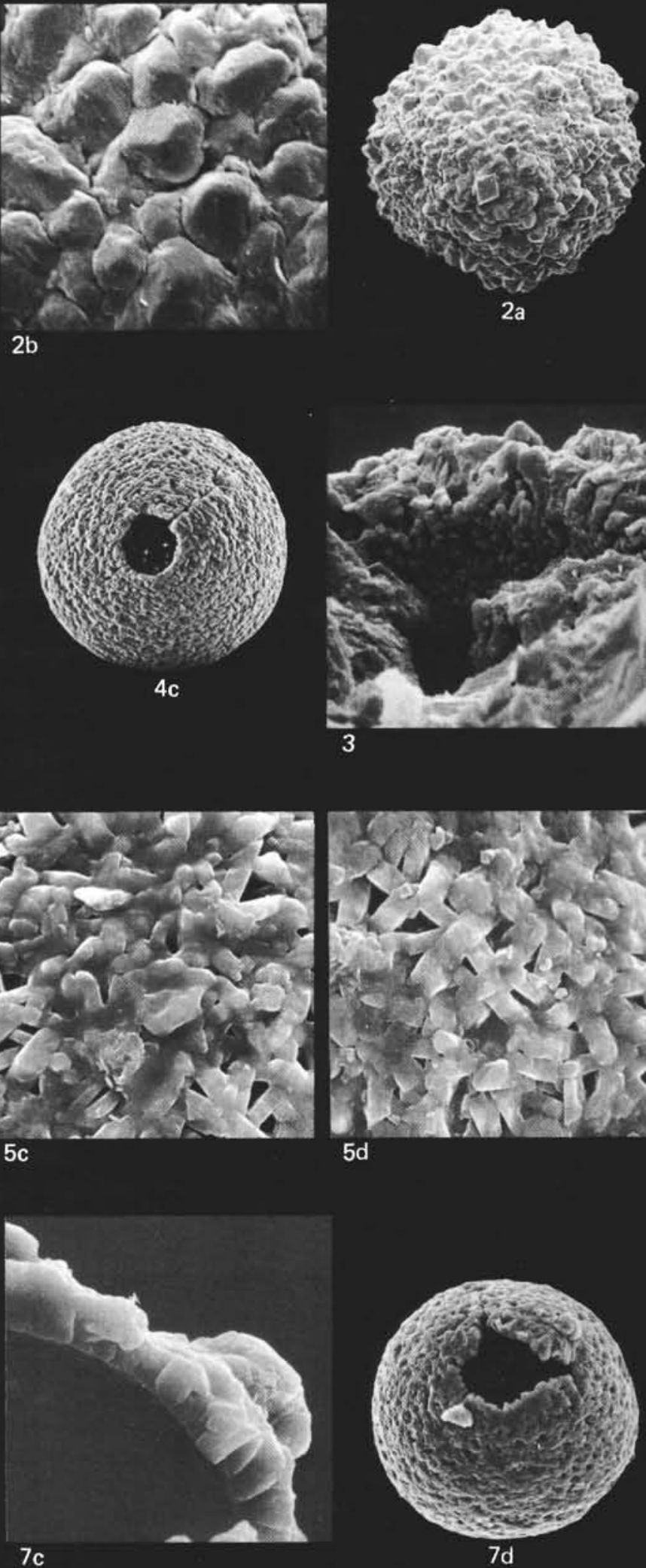
Figure $1 \quad$ Pithonella krasheninnikovi Bolli. Sample 41-369A-37-5, 63-65 cm.

1a. Lateral view. $\times 500,20 \mathrm{kv}$, No. 53201 .

lb. Distal view. $\times 500,20 \mathrm{kv}$, No. 53213 .

Ic. Detail of the lateral outer surface. $\times 2500,20$ kv, No. 53202.

Figure 2 Pithonella krasheninnikovi Bolli. Sample 41-369A-37-4, 63-65 cm.

Distal view of a specimen with outer layer removed. $\times 500,20 \mathrm{kv}$, No. 53193 .

Figure $3 \quad$ Pithonella krasheninnikovi Bolli. Sample 41-369A-38-2, 63-65 cm.

3a. Lateral view. $\times 500,10 \mathrm{kv}$, No. 53297.

3b. Detail of the distal end showing the thin outer layer of fine crystals covering the inner layer of coarse crystals. The edges of the aperture are irregularly bordered indicating part of the wall has been removed. $\times 500,10$ kv, No. 53304.

3c. Distal view showing an aperture or a broken section of the test at the distal end. $\times 500,10$ kv, No. 53303.

3d. Detail of the lateral outer wall, loosely arranged fine crystals partly surrounding irregular polygons. $\times 2500,10 \mathrm{kv}$, No. 53296 .

Figure $4 \quad$ Pithonella krasheninnikovi Bolli.

Sample 41-369A-38-5, 53-55 cm.

4a. Lateral view. The outer layer is mostly removed. $\times 500,10 \mathrm{kv}$, No. 53510 .

4b. Detail of the lateral surface. The heavy crystals of the inner layer are covered by the fine crystalline outer layer. $\times 2500,10 \mathrm{kv}$, No. 53511 .

4c. Distal view. The aperture is filled with sediment. $\times 500,10 \mathrm{kv}$, No. 53512 .

Figure $5 \quad$ Pithonella krasheninnikovi Bolli.

Sample 41-369A-38-5, 53-55 cm.

5a. Lateral view. The outer layer is totally removed, so that only the inner layer of coarse crystals is visible. At the distal ends, the size of the srystals as seen from the surface is reduced in comparison to the lateral parts. $\times 500,10 \mathrm{kv}$, No. 53509 .

$5 \mathrm{~b}$. Detail of the lateral wall showing the large crystals of the inner layer which are somewhat corroded. $\times 2500,10 \mathrm{kv}$, No. 53508 .

Figure $6 \quad$ Pithonella krasheninnikovi Bolli.

Sample 41-369A-37-4, 63-65 cm.

6a. Lateral view of a broken specimen. At the left side, the outer layer is partly removed. $\times 500,20 \mathrm{kv}$, No. 53154 .

6b. Detail of the lateral surface. The arrangement of the crystals is relatively dense, but similar to that in Figure $3 \mathrm{~d}$. Polygonal pseudopores remain open. $\times 2500$, $20 \mathrm{kv}$, No. 53155.

6c. Oblique view of the inner surface of the inner layer composed of densely packed euhedral crystals. $\times 2500,20 \mathrm{kv}$, No. 53156 . 


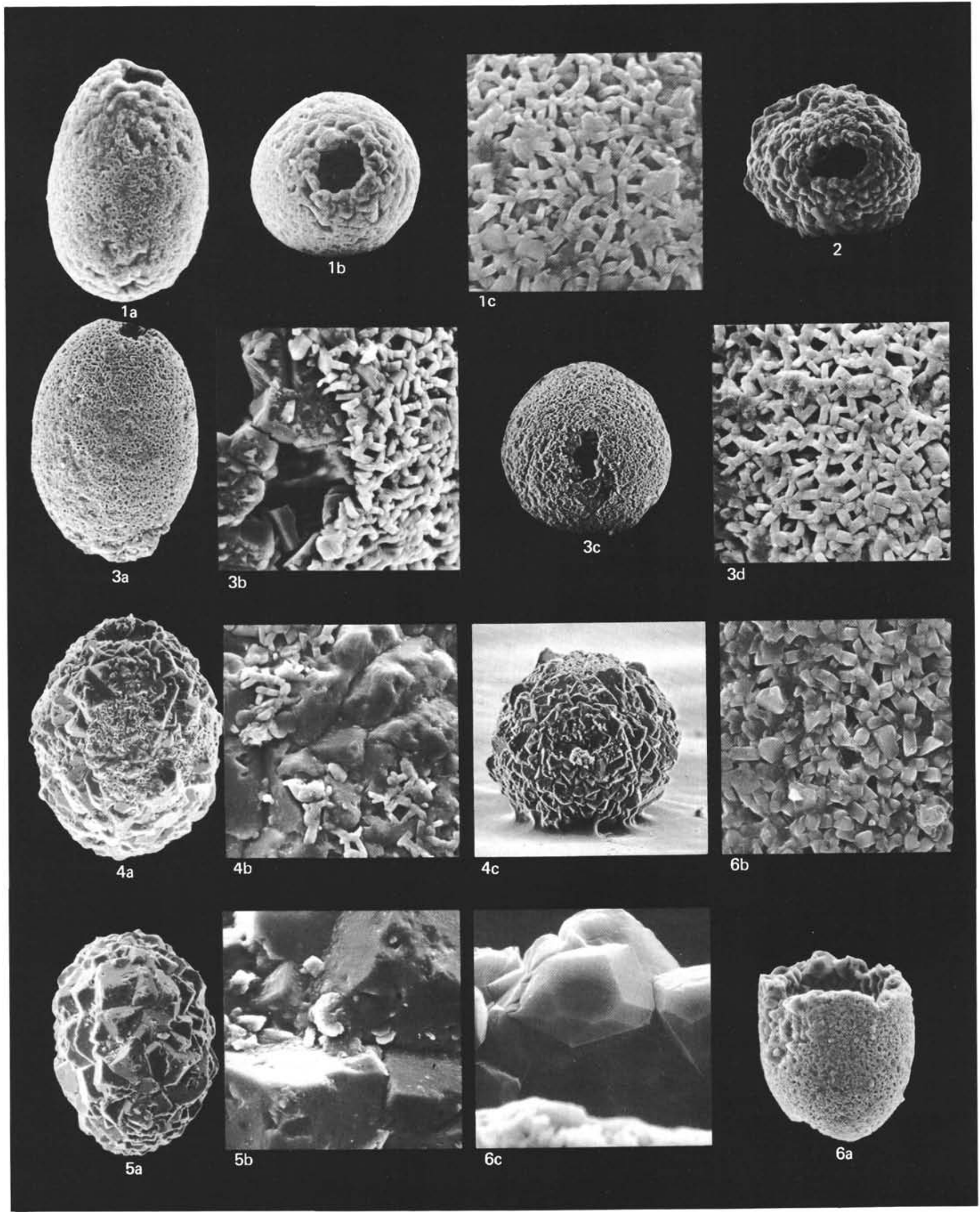




\section{PLATE 5}

Figure $1 \quad$ Pithonella cylindrica n. sp.

Sample 41-369A-37-4, 63-65 cm.

1a. Lateral view. $\times 500,20 \mathrm{kv}$, No. 53169 .

1b. Detail of the outer surface. The outer layer is partly removed, giving a view of the coarse crystals of the inner layer. $\times 2500,20 \mathrm{kv}$, No. 53168.

1c. Detail of the lateral surface with loosely arranged crystals of the outer layer. $\times 2500$, $20 \mathrm{kv}$, No. 53167.

Figure 2 Pithonella cylindrica n..sp.

Sample 41-369A-37-5, 63-65 cm.

2a. Lateral view. $\times 500,20 \mathrm{kv}$, No. 53207.

2b. Detail of the lateral surface. The size of the crystals of the outer layer is larger than those in Figure 1c. $\times 2500,20 \mathrm{kv}$, No. 53206 .

Figure $3 \quad$ Pithonella cylindrica n. sp.

Sample 41-369A-37-4, 63-65 cm.

3a. Lateral view. $\times 500,10 \mathrm{kv}$, No. 54250 .

3b. Detail of the apertural region showing a section through the coarse crystalline inner layer. $\times 2500,10 \mathrm{kv}$, No. 54252 .

3c. Detail of the lateral outer surface. The outer layer is partly removed. $\times 2500,10 \mathrm{kv}$, No. 54251 .

Figure 4 Pithonella cylindrica n. sp. (holotype).

Sample 41-369A-37-4, 63-65 cm.

4a. Lateral view. $\times 500,20 \mathrm{kv}$, No. 53152 .

4b. Detail of the artificially enlarged aperture showing the bilamellar wall, a fine crystalline outer layer, and a coarse crystalline inner layer. $\times 2500,20 \mathrm{kv}$, No. 53188 .

Figure $5 \quad$ Pithonella bilamellata n. sp.

Sample 41-369A-36-3, 23-25 cm.

Detail of the apertural region showing the bilamellate wall. $\times 2500,10 \mathrm{kv}$, No. 54052 .

Figure 6 Pithonella bilamellata n. sp. (holotype).

Sample 41-369A-36-3, 23-25 cm.

$6 a$. Oblique lateral view. $\times 500,10 \mathrm{kv}$, No. 54080 .

6b. Detail of the bilamellate wall and the inner surface of the test. $\times 2500,10 \mathrm{kv}$, No. 54078 .

6c. Detail of the lateral outer surface. $\times 2500,10$ kv, No. 54081.

6d. Detail of the inner surface. $\times 2500,10 \mathrm{kv}$, No. 54079. 


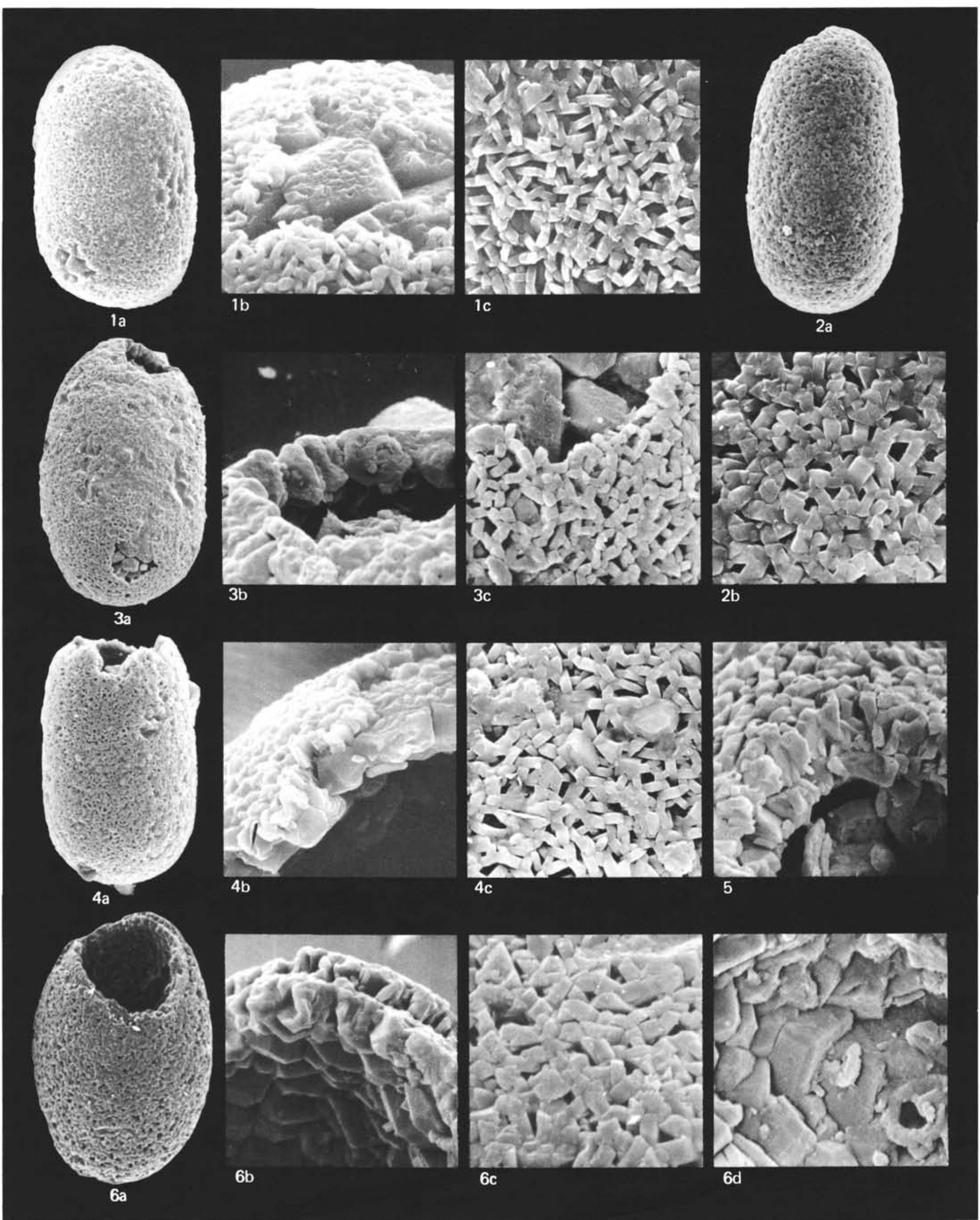




\section{PLATE 6}

Figure $1 \quad$ Pithonella bilamellata $\mathrm{n}$. sp.

Sample 41-369A-36-3, 23-25 cm. Same specimen as Plate 5, Figure 5.

1a. Distal view of the aperture. $\times 500,10 \mathrm{kv}$, No. 54050 .

lb. Detail of the lateral part of the outer layer. $\times 2500,10 \mathrm{kv}$, No. 54051 .

Figure 2 Pithonella bilamellata $\mathrm{n}$. sp.

Sample 41-369A-36-3, 23-25 cm.

2a. Lateral view. $\times 500,10 \mathrm{kv}$, No. 54061 .

2b. Detail of the lateral part of the outer surface. $\times 2500,10 \mathrm{kv}$, No. 54060 .

Figure 3 Pithonella trilamellata $\mathrm{n}$. sp. (holotype).

Sample 41-370-33, CC.

3a. View of the holotype. Note the circular form of the break which may follow the natural pattern. The outer wall lamella is partly removed. $\times 500,10 \mathrm{kv}$, No. 53319 .

3b. Detail of the multilayered wall. The inner, finely-crystalline layer is covered on both sides by a thin organic(?) lining, which did not show any details at magnifications up to $20,000 \times$. The interior (in the shadow) is filled with sediment and large euhedral crystals. $\times 2500,10 \mathrm{kv}$, No. 53318 .

3c. Detail of the outer surface of the outer wall. Large crystals leaving open interspaces between them form the pseudopores. $\times 2500,10$ kv, No. 53317.

Figure 4 Pithonella trilamellata $\mathrm{n}$. sp.

Sample 41-370-38-2, 98-100 cm.

4a. View of a specimen with the outer layer almost totally removed. $\times 500,10 \mathrm{kv}$, No. 52424 .

4b. Detail of the outer surface of the inner layer. The crystal growth is terminated by the lining which has been removed. $\times 2500,10 \mathrm{kv}$, No. 52425 .

Figure 5 Pithonella trilamellata n. sp.

Sample 41-370-44-1, 71-73 cm.

5a. Partly corroded specimen with a small aperture. Note the large crystals on the outer layer with smooth plate-like surfaces more densely arranged in comparison to Figure $3 \mathrm{a} . \times 500,10 \mathrm{kv}$, No. 53614.

5b. Detail of the broken external lamella showing the gradational transition between the oblique radially oriented small crystals and the heavy crystals of the outer part. Also note the spherical limitation by organic(?) lamella between external and internal layers. $\times 2500,10 \mathrm{kv}$, No. 53615 .

Figure $6 \quad$ Pithonella $\mathrm{sp}$. aff. trilamellata $\mathrm{n} . \mathrm{sp}$.

Sample 41-370-48-1, 65-67 cm.

6a. Lateral view. $\times 500,10 \mathrm{kv}$, No. 53757.

6b. Detail of the surface, which is probably an inner layer. $\times 2500,10$ kv, No. 53756.

Figure $7 \quad$ Pithonella trilamellata n. sp.

Sample 41-370-33, CC.

7a. View of a specimen whose outer layer is totally removed. The surface of the inner layer has a smooth texture but is corroded. $\times 500,10 \mathrm{kv}$, No. 53315 .

7b. Detail of the outer surface of the inner layer showing densely arranged, radially oriented small crystals. $\times 2500,10 \mathrm{kv}$, No. 53316 . 


\section{PLATE 6}

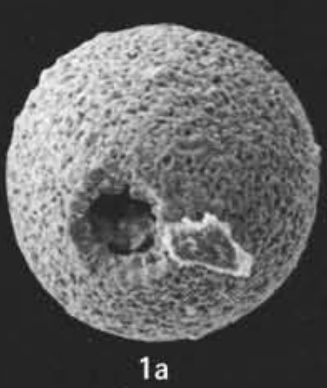

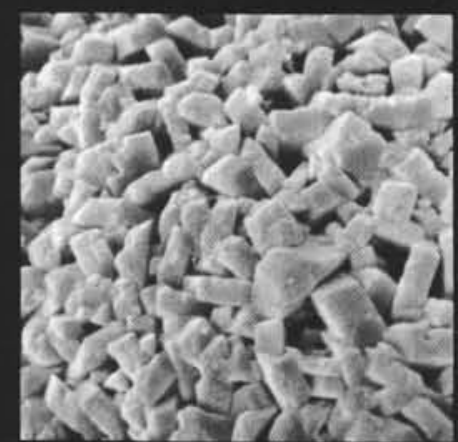

$1 \mathrm{~b}$

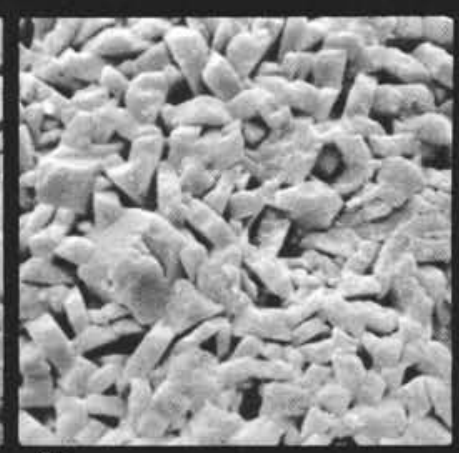

$2 \mathrm{~b}$

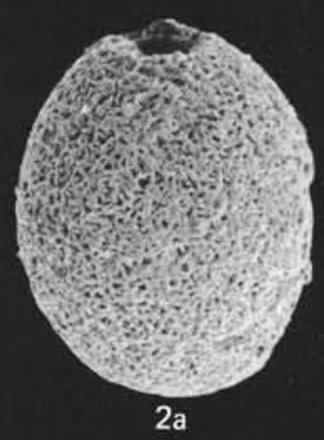

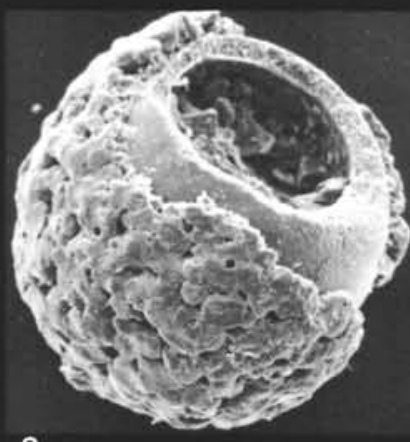

$3 a$

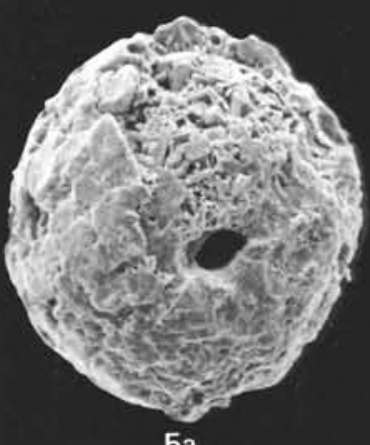

$5 a$

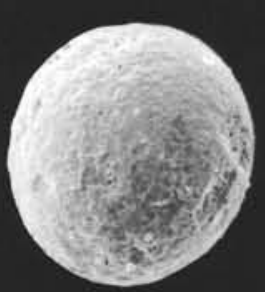

6a

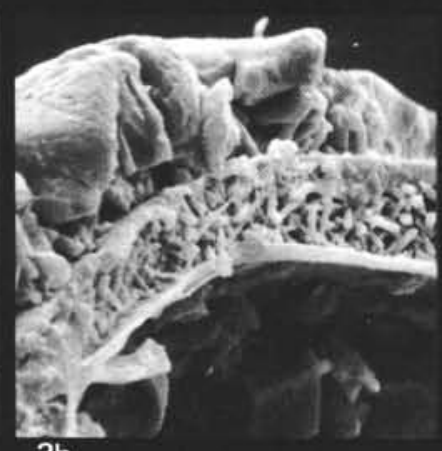

$3 b$

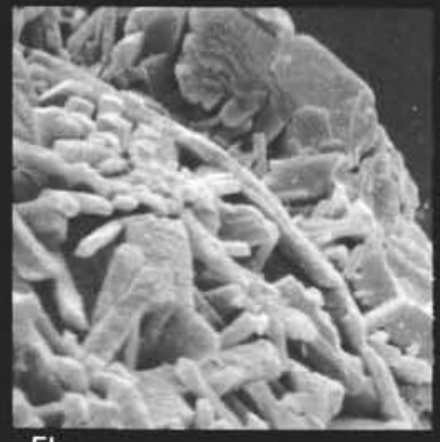

$5 b$

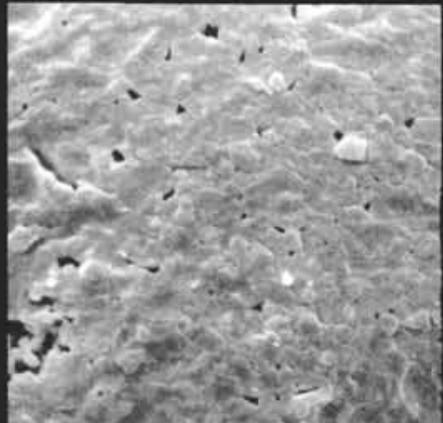

$6 b$

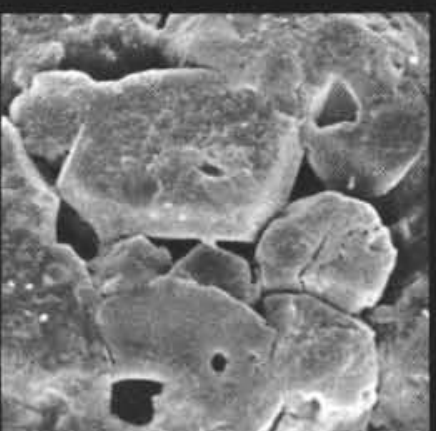

$3 c$
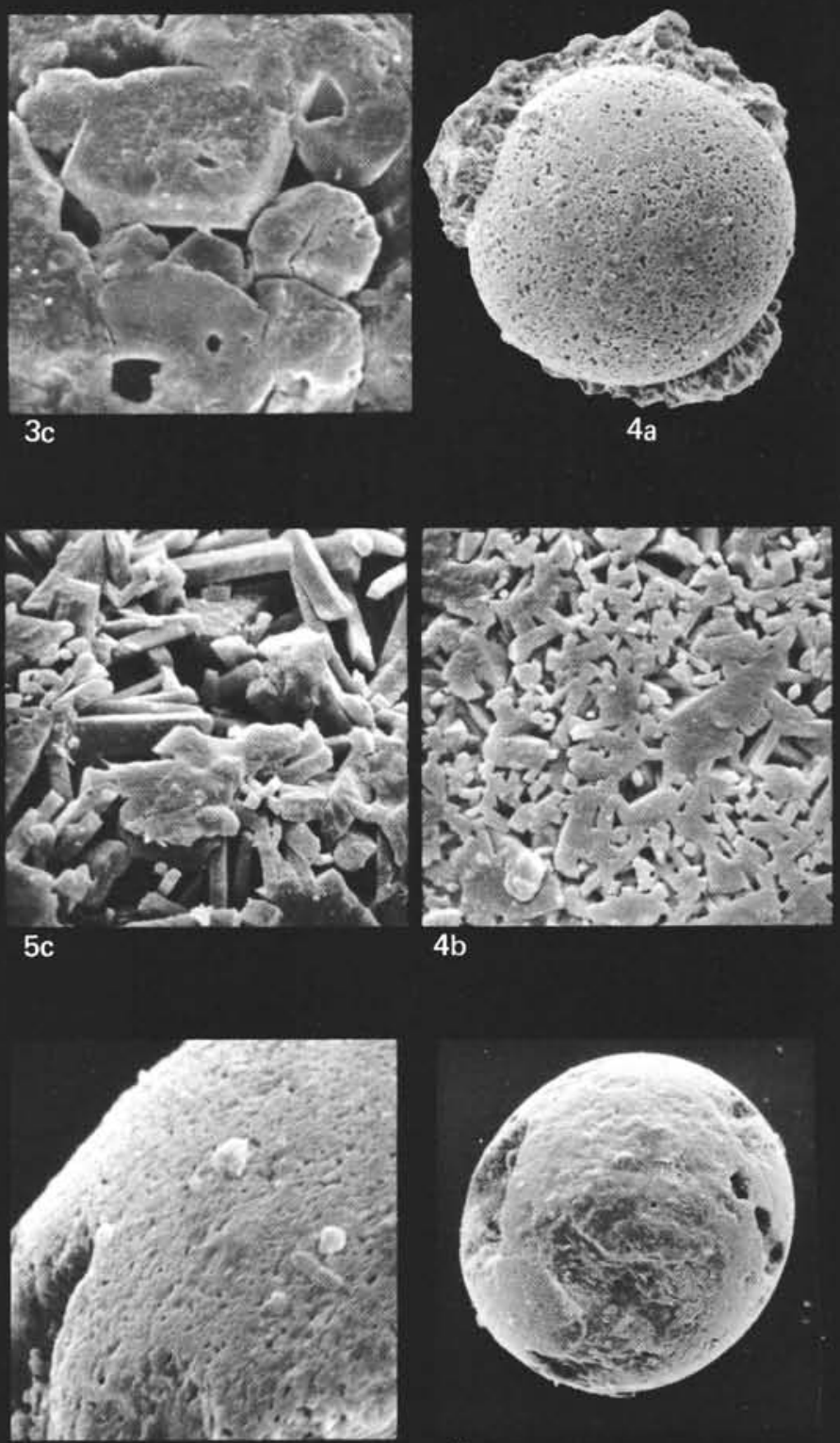

$7 \mathrm{~b}$

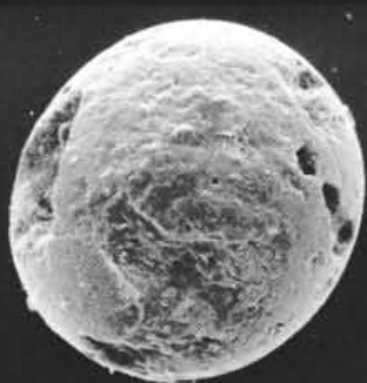

$7 a$ 


\section{PLATE 7}

Figure 1

Figure 2

Figure 3

Figure 4

Figure 5

Figure 6
Pithonella trilamellata $\mathrm{n} . \mathrm{sp}$.

Sample 41-370-42-2, $72-74 \mathrm{~cm}$.

1a. Artificially broken specimen. $\times 500,20 \mathrm{kv}$, No. 52982.

1b. Detail of the multilayered wall. The interior surface is partly visible showing a very smooth outline. Note the smaller thickness of the inner layer as compared to that of Plate 6, Figures 3b, 5b. $\times 2500,20 \mathrm{kv}$, No. 52983.

Pithonella trilamellata $\mathrm{n}$. sp.

Sample 41-370-39-1, 58-60 cm.

View of an artificially broken specimen. Note the organic(?) lining at the base of the outer lamella. $\times 500,10 \mathrm{kv}$, No. 53639 .

Pithonella multistrata $\mathrm{n}$. sp. (holotype). Sample 41-370-43-3, 63-65 cm.

3a. Lateral view of the broken specimen. Note the multilayered wall and the innermost organic(?) lining. $\times 500,10 \mathrm{kv}$, No. 54233 .

3b. Detail of the multilayered wall. Coarse crystals form the outer layer and fine crystals form the inner layer. $\times 2500,10 \mathrm{kv}$, No. 54234.

3c. Detail of the inner surface of the outer layer showing the very small crystals. $\times 2500,10$ kv, No. 54240 .

3d. Detail of the outer surface of the inner layer showing the random arrangement of fine crystals. $\times 2500,10 \mathrm{kv}$, No. 54237 .

3e. Lateral view of the holotype. $\times 500,10 \mathrm{kv}$, No. 53593.

3f. Detail of the outer surface. Plate-like crystals cover the small crystals of the intermediate layer. $\times 2500,10 \mathrm{kv}$, No. 53592 .

Pithonella multistrata $\mathrm{n}$. sp.

Sample 41-370-34-2, 73-75 cm.

4a. Oblique distal view of the aperture. $\times 525,10$ kv, No. 53686.

4b. Detail of the wall structure around the aperture showing the outer layer and an organic(?) lining. $\times 2500,10 \mathrm{kv}$, No. 53685 .

Pithonella multistrata $\mathrm{n} . \mathrm{sp}$.

Sample 41-370-46-5, 34-36 cm.

5a. Lateral view of a specimen with outer lamella removed. $\times 500,10 \mathrm{kv}$, No. 52563 .

5b. Detail of the outer surface. The small crystals of the intermediate layer are partly covered by a lining. $\times 2500,10 \mathrm{kv}$, No. 52562 .

Pithonella multistrata $\mathrm{n} . \mathrm{sp}$.

Sample 41-370-34-2, 73-75 cm.

6a. Lateral view. $\times 500,10 \mathrm{kv}$, No. 53668 .

6b. Detail of the outer surface of the test. $\times 2500$, $10 \mathrm{kv}$, No. 53667. 


\section{PLATE 7}

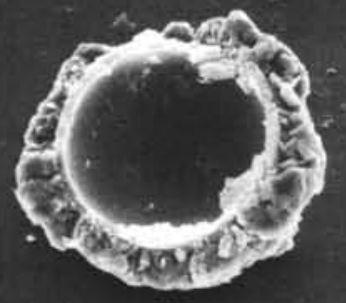

1a

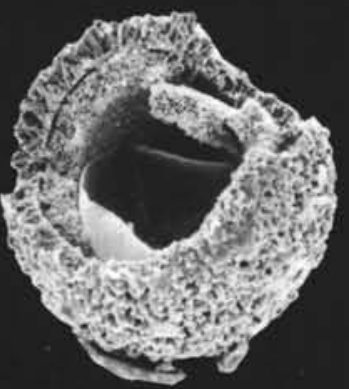

3a

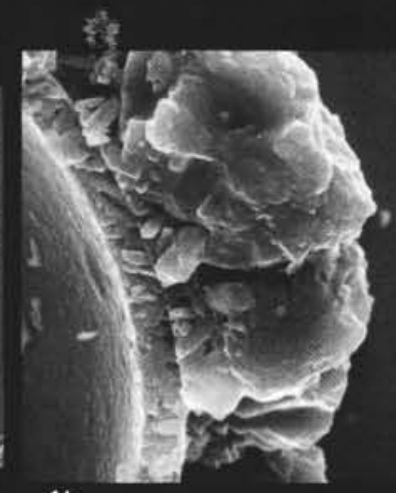

$1 b$

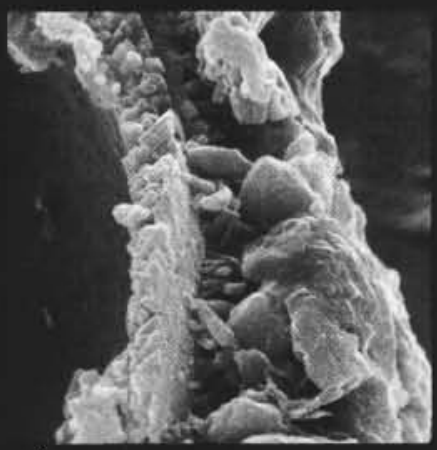

$1 \mathrm{c}$
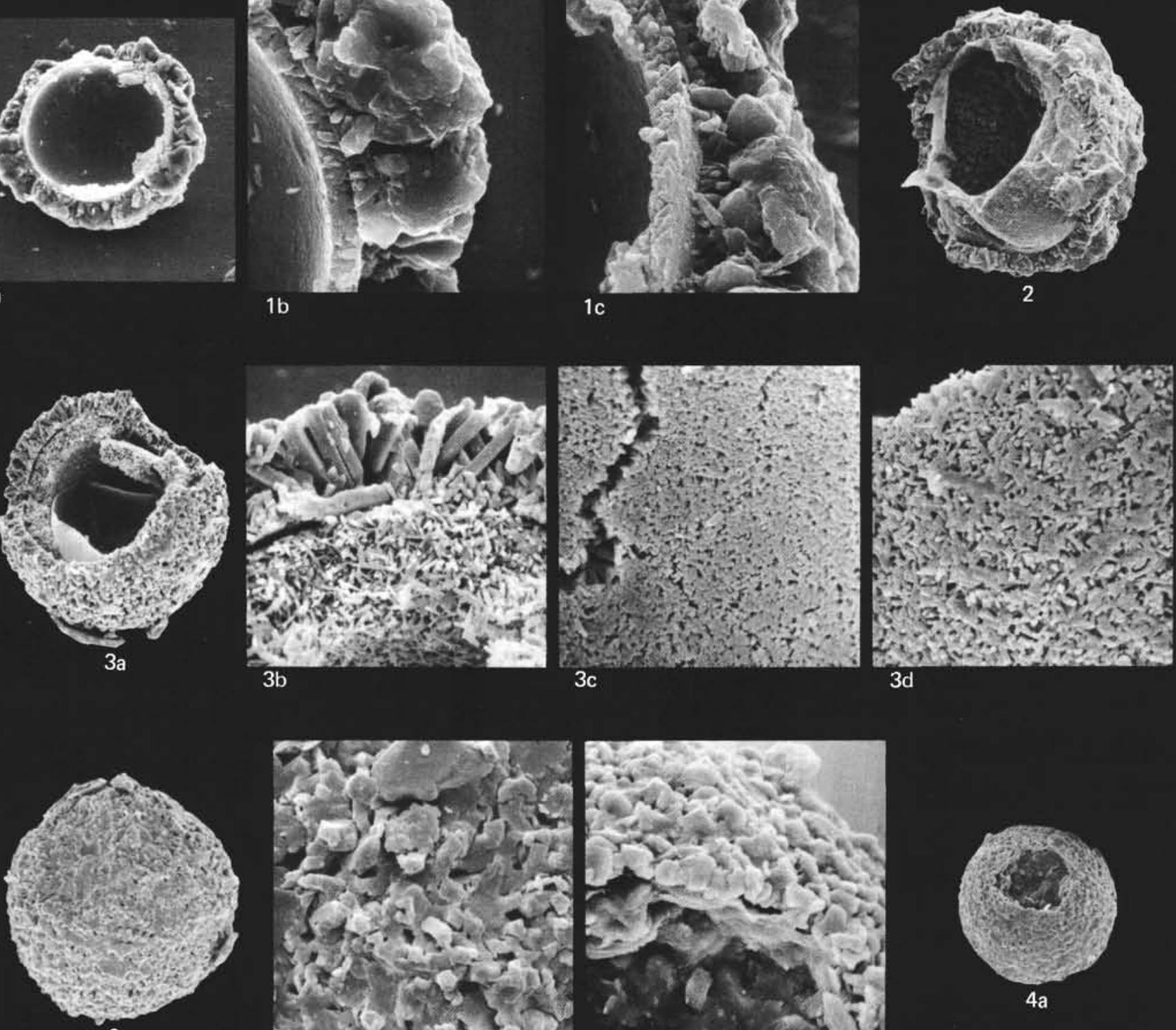

$3 e$

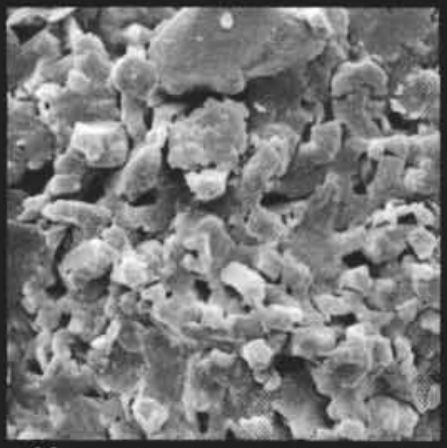

$3 f$

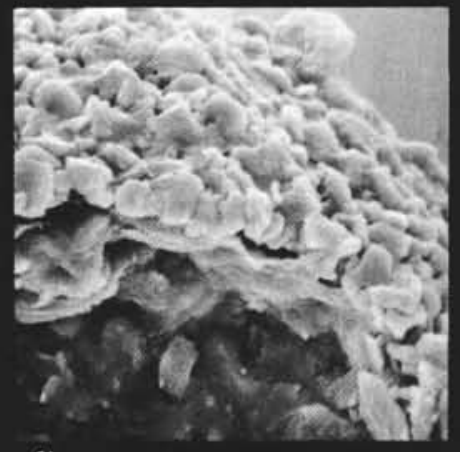

$4 b$
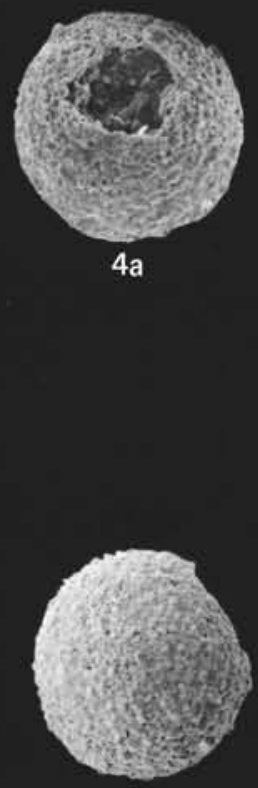

6a

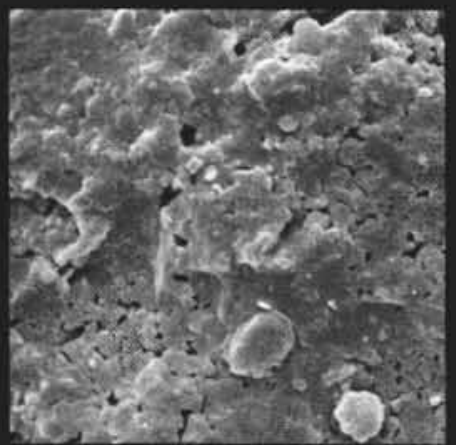

$5 b$

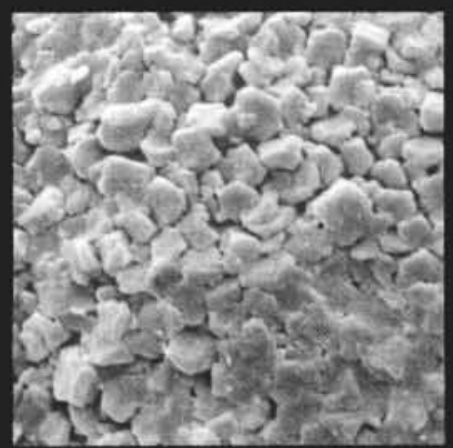

$6 b$ 


\section{PLATE 8}

Figure 1 Pithonella guttula n. sp. (holotype).

Sample 41-370-40-1, 39-41 cm.

1a. Lateral view of a specimen with outer layer partly removed. $\times 500,10 \mathrm{kv}$, No. 53337 .

1b. Detail of the different layers of the wall. The outer layer has coarse crystals and the inner layer has fine, needle-like crystals, separated by a smooth, organic(?) lining. $\times 2500,10 \mathrm{kv}$, No. 53339.

1c. Detail of a cross-section through the wall, showing the short needle-like crystals of the outer layer covered by and intergrading into large crystals of the outermost layer but below the organic(?) lining of the long needles of the inner layer. $\times 2500,10 \mathrm{kv}$, No. 55645.

Id. Another part of the fracture and surface of the inner layer below the lining. $\times 2500,10$ kv, No. 55646.

le. Detail of the outer surface of the test. Note the partially not filled interspaces between the large crystals. $\times 2500,10 \mathrm{kv}$, No. 53338 .

Figure 2 Pithonella guttula n. sp.

Sample 41-370-42-2, $72-74 \mathrm{~cm}$.

2a. Lateral view of a specimen with partly removed outer layers. $\times 500,10 \mathrm{kv}$, No. 52962.

2b. View of a section of the outer lamella. Note the oblique orientation of the large crystals. $\times 2500,10 \mathrm{kv}$, No. 52964 .

2c. View of the multilayered wall. Lower left shows crystals of the outer layer; lower right shows the organic(?) lining. In the middle of the picture, fine needle-like crystals of the inner layer are seen and upper right shows parts of an innermost lining or filling. $\times 2500,10 \mathrm{kv}$, No. 52963 .

Figure 3 Pithonella guttula n. sp. Sample 41-370-40-1, 39-41 cm.

3a. Lateral view. $\times 500,10 \mathrm{kv}$, No. 53348 .

3b. Detail of the outer surface of the test. The boundaries between the plate-like crystal surfaces are irregular but smooth. $\times 2500,10$ kv, No. 53349.

Figure 4 Pithonella guttula n. sp. Sample 41-370-44-1, 71-73 cm.

4a. Lateral view. $\times 500,10 \mathrm{kv}$, No. 53608 .

4b. Detail of the outer surface of the test. $\times 2500$, $10 \mathrm{kv}$, No. 53607.

Figure $5 \quad$ Pithonella sp. 2.

Sample 41-370-34-2, 73-75 cm.

5a. Lateral view. $\times 500,10 \mathrm{kv}$, No. 53664 .

5 b. Detail of the outer surface of the test. $\times 2500$, $10 \mathrm{kv}$, No. 53663.

Figure 6 Pithonella sp. indet.

Sample 41-370-28, CC.

6a. Lateral view of a specimen whose outer layer is probably missing. $\times 500,10 \mathrm{kv}$, No. 53690 .

6b. Detail of the surface of the specimen. $\times 2500$, $10 \mathrm{kv}$, No. 53691. 


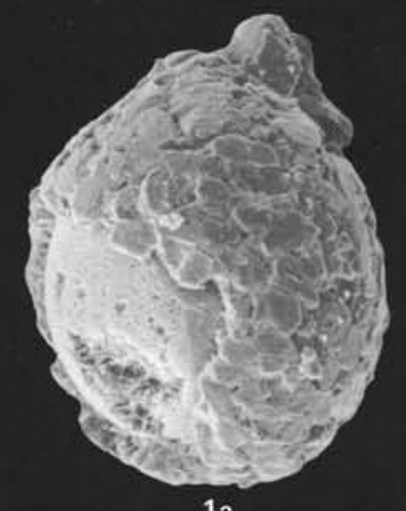

$1 \mathrm{a}$

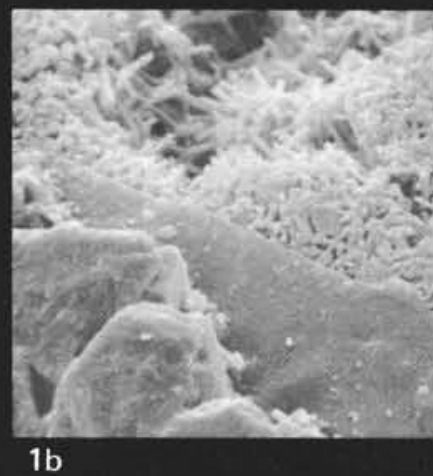

$1 \mathrm{~b}$

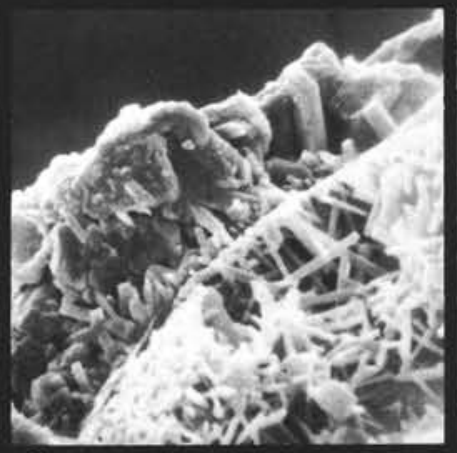

1c
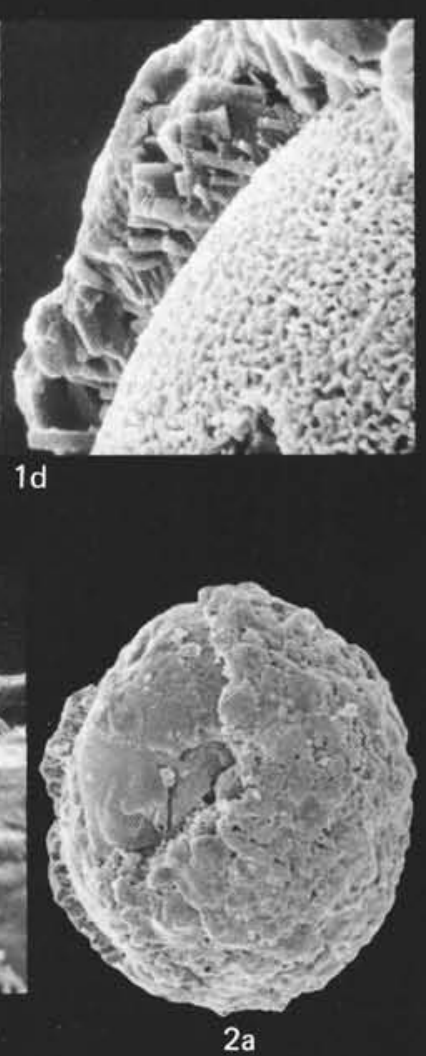

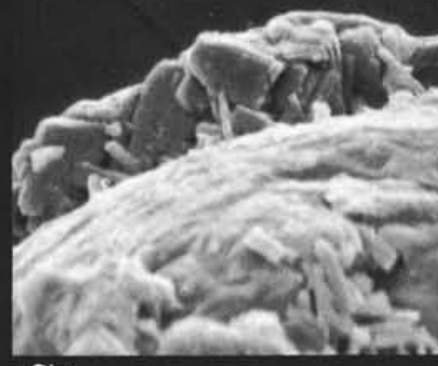

$2 b$
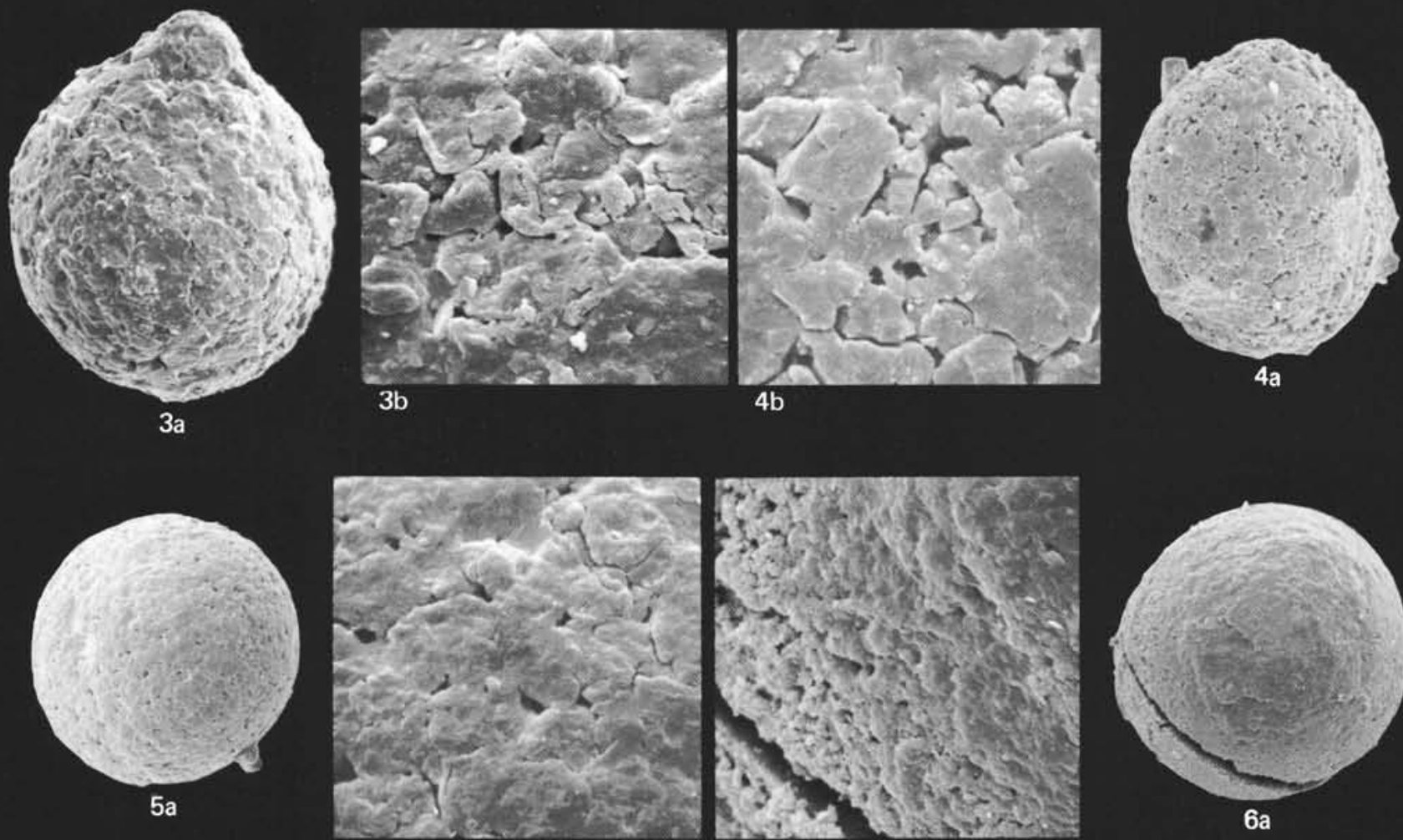

$5 b$

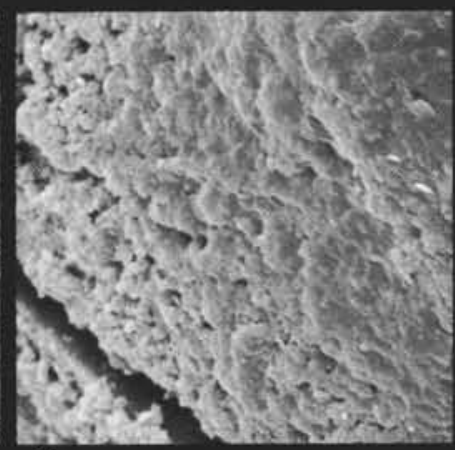

$6 b$

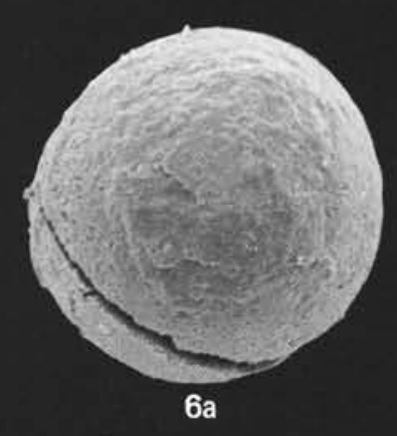

